\title{
People and pixels in the Sahel: a study linking coarse-resolution remote sensing observations to land users' perceptions of their changing environment in Senegal
}

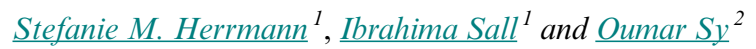

\begin{abstract}
Mounting evidence from satellite observations of a re-greening across much of the Sahel and Sudan zones over the past three decades has raised questions about the extent and reversibility of desertification. Historical ground data that could help in interpreting the re-greening are scarce. To fill that void, we tapped into the collective memories of local land users from central and western Senegal in 39 focus groups and assessed the spatial association between their perceptions of vegetation changes over time and remote sensing-derived trends. To provide context to the vegetation changes, we also explored the land users' perspective on the evolution of other environmental and human variables that are potentially related to the greening, using participatory research methods. While increases in vegetation were confirmed by the study participants for certain areas, which spatially corresponded to satellite-observed re-greening, vegetation degradation dominated their perceptions of change. This degradation, although spatially extensive according to land users, flies under the radar of coarse-resolution remote sensing data because it is not necessarily associated with a decrease in biomass but rather with undesired changes in species composition. Few significant differences were found in the perceived trends of population pressure, environmental, and livelihood variables between communities that have greened up according to satellite data and those that have not. Our findings challenge the prevailing chain of assumptions of the satellite-observed greening trend indicating an improvement of environmental conditions in the sense of a rehabilitation of the vegetation cover after the great droughts of the 1970s and 1980s, and the improvement of environmental conditions possibly translating into more stable livelihoods and greater well-being of the populations. For monitoring desertification and rehabilitation, there is a need to develop remote sensing-based indicators that better reflect the changes in the biophysical environment that matter most to the land users.
\end{abstract}

Key Words: desertification; human-environment interactions; NDVI; participatory methods; re-greening; transhumance

\section{INTRODUCTION}

While interactions between humans and their natural environment have long been acknowledged (e.g., Marsh 1864, Thomas 1956), recent years have seen an upsurge in interdisciplinary research and a growing recognition of the importance of integrated studies of human and natural systems to investigate patterns and processes that cannot be understood from either a social or a natural science perspective separately (Liu et al. 2007a,b). With the increasing availability of satellite observations at various resolutions and a growing interdisciplinary community of scientists interested in sustainable development and related issues of human-environment relationships, combining remote sensing with social science data has opened new research directions (Liverman et al. 1998, Fox et al. 2003). Particular interest has been placed on remote sensing of vegetation as the interface between livelihoods and ecosystems (DeFries et al. 2008). Most of the work on coupled human and natural systems has been theoretical (Liu et al. 2007a), and most empirical studies combining remote sensing and social science have focused on the humid tropics (Liverman et al. 1998 and others), where land-cover changes such as deforestation are clearly detectable from satellite observations. In drylands, the issue of desertification is a prime example of a humanenvironment system in which ecological and social dynamics are fundamentally interwoven and need to be assessed in an integrated manner (Reynolds et al. 2007). However, little work linking remote sensing and social science has so far been conducted in drylands, where extensive land-use systems, as well as the large interannual variability of rainfall and vegetation productivity, pose particular challenges for this type of study (Lambin et al. 2009). Motivated by earlier findings of a greening trend in the Sahel, which put the extent of desertification into question, we use a perception-based approach to elicit the observations of local land users on environmental changes and to compare those observations with coarse-scale remote sensing observations of greenness trends.

\section{Regional background}

The West African Sahel is a transition zone between the arid Sahara desert to the north and the Sudanian savanna and Guinean forest regions to the south. Its northern boundary is commonly defined by the $200-\mathrm{mm}$ isohyet and its southern boundary by the $600-\mathrm{mm}$ isohyet. The climate of the Sahel is characterized by a marked seasonality, with a long dry season and a short humid season (Nicholson 2013), to which the vegetation cycle closely responds. Not only the scarcity of rainfall, but also its interannual variability and unpredictability, are the most important constraints to both the ecosystem and the livelihood of the population. The Sahelian climate and the mostly sandy soils found in the region support a mix of woody and herbaceous vegetation. Trees and shrubs tend to be scarcer and shorter in the more arid north. Tree savanna and remnants of savanna woodlands can be found in the Sahelian-Sudanian transition zone in the south. The fast-growing and predominantly rural population of the Sahel is believed to exert an increasing pressure on the region's limited natural resources (Sissoko et al. 2011). Agriculture (rainfed farming and pastoralism) is the main livelihood and closely 
connects people to their environment. With rainfall marginal for rainfed farming, livestock production plays an increasingly important role toward the north (Batterbury and Warren 2001). Despite land-use conflicts and incentives for sedentarization, livestock mobility remains a major adaptation strategy to uncertainty and risk, which optimizes usage of spatially and temporally variable pasture productivity (Niamir-Fuller 1999). Local land users, and pastoralists in particular, have traditionally received much blame for degrading the environment (e.g., Sinclair and Fryxell 1985); but more recently, the perception has been shifting toward a recognition of local knowledge and of positive environmental impacts of good land management practices (Mortimore and Adams 1999, Reij et al. 2009).

The Sahel has received heightened scientific and political interest since a series of severe drought years hit the region in the 1970s, causing widespread environmental degradation and human suffering to its rural populations (Batterbury 2001). The causes and extent of this desertification crisis have been intensely debated, and the debate has evolved in conjunction with major developments in the fields of climate studies, ecology, and social and political sciences (Herrmann and Hutchinson 2005). In the past decade, the increasing availability of remote-sensing observations has sustained the debate, which had hitherto been mostly driven by anecdotal ground-based observations.

\section{The greening conundrum}

Contrary to the mainstream paradigm of irreversible land degradation in the Sahel, monthly coarse spatial resolution satellite observations of vegetation greenness show a positive trend over large parts of this region, suggesting an increase in biomass since the beginning of the data record in 1982. A number of studies have confirmed this greening trend using slightly different data sets and methodologies (e.g., Eklundh and Olsson 2003, Anyamba and Tucker 2005, Seaquist et al. 2006, Heumann et al. 2007, Helldén and Tottrup 2008). Increasing rainfall since the severe droughts of the 1970s and 1980s (Nicholson 2005, Ali and Lebel 2009) is believed to have contributed to the greening; however, it does not appear to explain it fully. Combining vegetation greenness and rainfall data, Herrmann et al. (2005) postulate that the greening exceeds what can be explained by increases in rainfall alone and suggest the contribution of other factors, which may be related to land management. Analyzing rain-use efficiencies, Fensholt et al. (2013) also found no indication for widespread nonrainfall-related land degradation, which corroborates earlier findings by Prince et al. (1998).

Together, these findings provide growing evidence against the notion of widespread degradation in the sense that they suggest an increase rather than a decrease in vegetation biomass, at least at coarser scales. However, speculation is rife as to how to interpret this greening trend (e.g., Olsson et al. 2005). Most remote sensing studies have not gone any further than documenting the trend or have relied on modeling approaches using coarse-resolution climate, demographic, and land-use data sets to generate potential explanations (e.g., Seaquist et al. 2009). Ground-truthing studies involving field data are rare, which is hardly surprising given the challenge of spatial scales and the lack of historical field data necessary for assessing changes over time. Herrmann and Tappan (2013) studied a number of sites in central Senegal for which historical field data were available and noted an impoverishment of woody vegetation cover since the early 1980 s despite the overall greening trend, suggesting that the positive connotations often associated with "greening" might be misguided.

In contrast, truly positive developments on the ground have been described by Reij et al. (2005) and Sendzimir et al. (2011), who documented increasing on-field tree densities and improvements in soil and water conservation in formerly degraded areas of Burkina Faso and Niger, which became known as the "regreening" of the Sahel. However, while those areas do show a greening trend in coarse-resolution remote sensing observations, they do not stand out above other areas in the Sahel, where such improvements have not taken place (Reij et al. 2009).

\section{Theoretical background, objectives, and approach}

Our research is situated within the interdisciplinary framework of land-change science, which seeks to understand the dynamics of land use and land cover as a coupled human-environment system (Fox et al. 2003, Turner and Robbins 2008). It follows the basic tenets of, and seeks to provide empirical evidence for, the Dahlem desertification paradigm (DDP; now drylands development paradigm; Reynolds and Stafford Smith 2002, Reynolds et al. 2007), which adopts elements from panarchy theory (Gunderson and Holling 2002). Among other elements, these include the importance of inter-relationships among biophysical and socioeconomic factors, slow variables as critical system determinants, the presence of thresholds, and the value of local environmental knowledge (Stafford Smith and Reynolds 2002).

The overarching goal of our research is to shed some light on what the satellite-observed greening trend might mean on the ground. Our main objectives were: (1) to assess systematically the spatial association between the satellite-observed greening trend and the local population's perceptions of vegetation degradation and rehabilitation, (2) to retrace the evolutions of environmental variables, human and livestock pressures, and livelihoods over five decades through the perspective of local land users, and (3) to contribute to the understanding of the inter-relationships among those evolutions and assess their relevance to the greening trend. To this end, we adopted an intermediate scale between local-scale, idiosyncratic case studies of individual villages (e.g., Batterbury and Warren 1999, Dahlberg and Blaikie 1999, Nielsen and Reenberg 2010, Reenberg et al. 2013; O. Murzabekov, L. Gordon, E. Enfors, L. Börjeson, T. Abasse, and M. Adamou unpublished manuscript) and regional-scale coarse-resolution remote sensing studies. Along the same lines, our choice of methodology attempts to bridge the gap between the qualitative ethnographic and quantitative empirical approaches of knowledge generation.

\section{METHODS}

The methods we used include processing of time series of remotesensing data as well as collection and analysis of social science data, mostly adapted from the pool of participatory research methods (Chambers 1981, 1994, Campbell 2001). The former is explained in detail in Herrmann et al. (2005). Thus, we place more emphasis on the latter subject and on bringing the two together.

\section{Study area}

The study was carried out in Senegal, the westernmost of the Sahelian countries. With its semi-arid climate, frequent droughts, and an estimated $70 \%$ of the population depending directly on 
Table 1. Geographic characterization of the five regions in Senegal that are part of the study area.

\begin{tabular}{|c|c|c|c|c|c|c|}
\hline Region & Climate $\uparrow$ & Land cover/use & $\begin{array}{c}\text { Population } \\
\text { density (people/ } \\
\left.\mathrm{km}^{2}\right) \S \\
\end{array}$ & $\begin{array}{c}\text { Primary } \\
\text { livelihoods }\end{array}$ & Ethnic groups| & Vegetation productivity \\
\hline Bawol & $\begin{array}{l}\text { Sudano-Sahelian: } \\
\text { MAR } 485 \mathrm{~mm} \\
{[450-510 \mathrm{~mm}]}\end{array}$ & $\begin{array}{c}\text { Agriculture }(74 \%) \\
\text { Savanna }(17 \%) \\
\text { Settlements }(5 \%) \\
\text { Steppe }(2 \%) \\
\text { Other }(1 \%)\end{array}$ & 292 & Agricultural & Serer, Wolof & $\begin{array}{c}\text { NDVI } 0.25 \\
{[0-0.34]} \\
\text { NDVI trend } 0.8 \\
{[-0.7 \text { to } 3.6]}\end{array}$ \\
\hline Cayor & $\begin{array}{l}\text { Sudano-Sahelian: } \\
\text { MAR } 415 \mathrm{~mm} \\
\text { [365-470 mm] }\end{array}$ & $\begin{array}{c}\text { Agriculture }(57 \%) \\
\text { Savanna }(35 \%) \\
\text { Settlements }(2 \%) \\
\text { Steppe }(2 \%) \\
\text { Other }(4 \%)\end{array}$ & 238 & Agricultural & Wolof & $\begin{array}{l}\text { NDVI } 0.23 \\
{[0-0.34]} \\
\text { NDVI trend } 0.78 \\
{[-1.2 \text { to } 2.5]}\end{array}$ \\
\hline Jolof & $\begin{array}{c}\text { Sahelian and } \\
\text { Sudano-Sahelian: } \\
\text { MAR } 450 \mathrm{~mm} \\
{[370-515 \mathrm{~mm}]}\end{array}$ & $\begin{array}{c}\text { Savanna }(88 \%) \\
\& \# 160 \text { :Agriculture }(7 \%) \\
\text { Steppe }(4 \%) \\
\text { Other }(1 \%)\end{array}$ & 15 & Pastoral & Peulh, Wolof & $\begin{array}{c}\text { NDVI } 0.26 \\
{[0.2-0.33]} \\
\text { NDVI trend } 1.68 \\
{[-0.6 \text { to } 4.6]}\end{array}$ \\
\hline Saloum & $\begin{array}{l}\text { Sudano-Sahelian: } \\
\text { MAR } 615 \mathrm{~mm} \\
\text { [500-750 mm] }\end{array}$ & $\begin{array}{c}\text { Agriculture }(56 \%) \\
\text { Savanna }(35 \%) \\
\text { Settlements }(1 \%) \\
\text { Other }(7 \%)\end{array}$ & 85 & Agro-pastoral & $\begin{array}{l}\text { Wolof, Peulh, } \\
\text { Serer }\end{array}$ & $\begin{array}{l}\text { NDVI } 0.3 \\
{[0.11-0.44]} \\
\text { NDVI trend } 1.7 \\
{[-0.38 \text { to } 4.6]}\end{array}$ \\
\hline Waalo & $\begin{array}{l}\text { Sahelian: } \\
\text { MAR } 350 \mathrm{~mm} \\
\text { [300-390 mm] }\end{array}$ & $\begin{array}{c}\text { Savanna }(50 \%) \\
\text { Wetland }(14 \%) \\
\text { Agriculture }(11 \%) \\
\text { Steppe }(11 \%) \\
\text { Irrigation }(7 \%) \\
\text { Water bodies }(5 \%) \\
\text { Other }(2 \%) \\
\end{array}$ & 71 & Agro-pastoral & Wolof, Peulh & $\begin{array}{l}\text { NDVI } 0.2 \\
{[0.03-0.42]} \\
\text { NDVI trend } 1.4 \\
{[-0.4 \text { to } 5]}\end{array}$ \\
\hline
\end{tabular}

$\dagger$ Climate is characterized by the mean annual rainfall (MAR) and its spatial range within each region (in square brackets); mean annual rainfall is derived from the Tropical Rainfall Measuring Mission (TRMM) satellite rainfall estimates 2000-2010.

\$Land cover/land use percentages are based on visual interpretation of Landsat satellite imagery from 2010 (United States Geological Survey, Earth Resources Observation and Science [EROS] Center, unpublished map of Senegal land cover 2010).

§Averaged by region from 2010 population estimates database (United Nations Environment Programme/Global Resource Information Database [UNEP/GRID]).

|Source: Pelissier (1983).

TVegetation productivity is described by the mean annual Normalized Difference Vegetation Index (NDVI) and its spatial range within each region (in square brackets) as well as mean linear trends (slope of linear regression $\times 10^{3}$ ) from 1982 to 2008 and their spatial range within each region (in square brackets).

their natural environment for agricultural and pastoral activities (Food and Agriculture Organization 2013), Senegal exemplifies many of the challenges that the West African Sahel region faces.

The study area, defined by the spatial extent of observations made by our informants (see Map activity), includes a large part of western and central Senegal, which covers roughly $75,000 \mathrm{~km}^{2}$ or $40 \%$ of the national territory (Fig. 1). It encompasses considerable environmental and socioeconomic diversity and intersects five historical regions, which go back to pre-colonial kingdoms and empires and are still most widely used by the populations as geographic references (Table 1). Land use comprises a mixture of crop cultivation and pastoralism, with cultivation predominant in the western and southern parts of the study area and pastoralism more important in the northern and eastern parts (Tappan et al. 2004, Mbow et al. 2008, Pires 2012). The pastoralist practice of transhumance, i.e., the seasonal mobility of livestock and herders with a stationary home base, links the regions spatially and functionally (Leclerc and Sy 2011).

\section{Satellite observations}

We used monthly time series of the normalized difference vegetation index (NDVI), a vegetation greenness index that has been shown to be related to vegetation productivity (Tucker 1979, Tucker et al. 1991), to estimate trends in vegetation productivity over time. The NDVI and its derivatives have served as quantitative indicators of global land degradation and rehabilitation, replacing qualitative expert judgment deemed out of date (Bai et al. 2008). Time series of NDVI data are available from different satellite sensors in the medium to coarse resolution realm. Because land degradation and rehabilitation are longer term phenomena that need to be distinguished from short-term fluctuations of vegetation productivity, we used the longest continuous time series available, the 8-km Global Inventory Modelling and Mapping Studies (GIMMS) data set from 1982 to 2008 (Tucker et al. 2005, Brown et al. 2006). We determined trends in NDVI by linear regression between the monthly NDVI observations and time, the slope of the regression being the measure of long-term change in vegetation productivity (Herrmann et al. 2005). Significantly positive slopes are referred 
to as "greening," whereas significantly negative slopes, which rarely occurred in the study area, are referred to as degradation of the vegetation cover.

Fig. 1. Home communities and routes of transhumance of the informants, which determine the spatial extent of the study region. The home communities are color-coded by the historical region in which they occur.

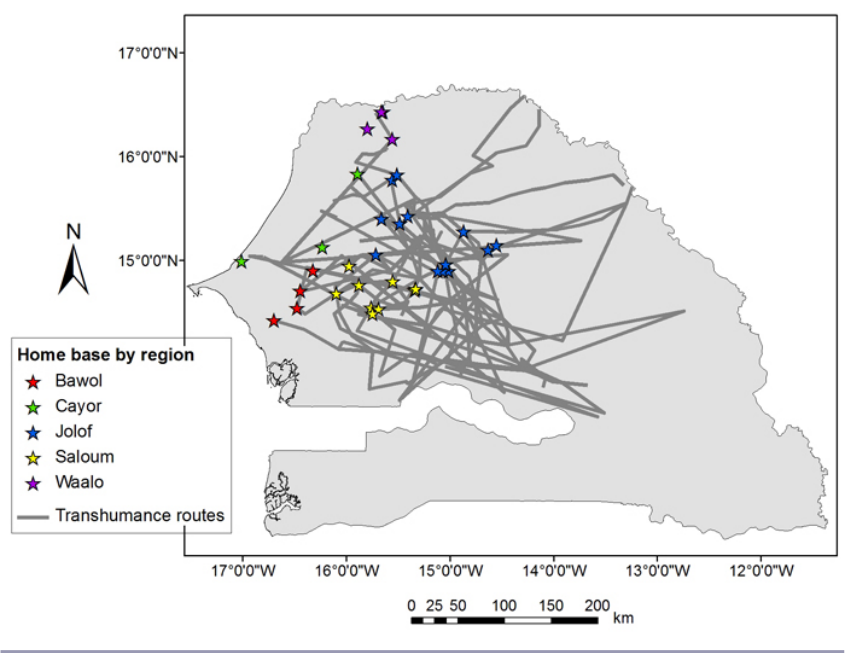

\section{Informants}

As farmers or pastoralists, the rural Senegalese rely heavily on the resources of their environment, i.e., vegetation, soil, and water resources, to meet their livelihood needs. Their reliance on the environment and endurance of the vagaries of climate afford them a detailed knowledge of their environment, accumulated through continuous presence on and use of the land. Local environmental knowledge has received increasing interest as a valuable source of information and may provide new insights for improving existing scientific knowledge (World Bank 1998, Adriansen 2008, Oba 2012).

Whereas sedentary farmers cultivate in and are mostly familiar with an area of several kilometers radius around their homestead, pastoralism takes place at more extensive spatial scales and results in familiarity with larger areas, albeit in a more cursory manner. Hence, the spatial scale of transhumant pastoralism is a good match for comparison with vegetation greenness data derived from coarse resolution satellite imagery. We therefore targeted primarily transhumant pastoralists as informants and sought their observations on the vegetation cover for the areas with which they are familiar. As we were interested in the longer term perspective of trends and changes, we included older individuals in our discussions when possible, who had been involved in transhumance for at least the last 25 years. The transhumant participants of our study were recruited in and around local and regional centers, where several migration routes intersected at the time of year of the field work: Dahra, Thiel, Velingara, Mbar, and Touba. Our discussions for the most part took place in the informants' homes or temporary camps for those who were in transit. Thirty focus groups of two to ten participants each were formed with transhumant pastoralists. The different focus groups represented different ethnic groups (21 groups of Peulh, 9 of
Serer) and areas of origin (see map of home communities, Fig. 1); the participants of one focus group, however, belonged to the same community and were on transhumance together.

To fill some gaps in the spatial representation of observations, we supplemented this set of focus groups with nine focus groups of sedentary farmers, of which four groups were Wolof, four Peulh, and one Serer. These focus groups were recruited in regions that were less well represented by home communities of the transhumant pastoralists as well as in locations that stood out by a particularly strong greening trend.

Additional information on environmental trends was obtained through semi-structured key informant interviews with local experts, including representatives of the local administration and extension agents in the fields of livestock and water management.

\section{Focus group discussions with semi-quantitative participatory activities}

A total of 39 focus group discussions was carried out in three field trips between August 2011 and January 2013, aimed at eliciting people's perceptions of their changing environment. The discussions were held in Wolof or Pulaar and moderated by the second and third authors of this manuscript. Although focus group discussions are traditionally described as a qualitative, exploratory research method (Stewart et al. 2007), which is often used as a first step to generate hypotheses for further quantitative research, we added a semi-quantitative element to the discussions by animating them with two participatory activities (map and matrix activities). The activities helped to keep participants engaged and to generate more systematic data, without imposing the rigidity of a questionnaire. They ensured that every focus group was exposed to the same stimuli for discussion, thus making the outcomes more comparable. Our sample size of 39 focus groups is considerably larger than what is traditionally used in participatory rural appraisal, which is often built on very few informants.

\section{Map activity}

With the pastoralist focus groups, we generated maps as spatial representations of their perceptions of vegetation change along their transhumance routes. To this end, we presented to each group a base map of the study area, with the locations of major towns and villages, roads, boreholes, watercourses, and protected forests indicated for orientation (Fig. 2). We inquired about the location of their home community and marked it with a yellow button. Next, we discussed their mobility and marked their usual routes of transhumance on the map with grey buttons. This established the extent of the geographic space with which our informants are familiar and for which they could share their observations. Since most of the participants were not literate or familiar with the concept of a map, the buttons were placed by our assistant according to the detailed description of locations and routes.

We then engaged the focus group participants in a conversation about changes in vegetation cover that they may have observed over the years. We explained how our interest in their perspective was motivated by images taken from satellites that regularly passed over the area and showed some changes over time, which however needed to be confirmed on the ground. We emphasized that we were primarily interested in changes that made the 
landscape appear more or less green. We asked specifically about any locations where they have observed a negative change over the past 25 years, that is, loss or degradation of vegetation, and marked those locations with red buttons, and about locations where positive change took place, that is, a greening up of the landscape due to denser or healthier vegetation cover, and marked those locations with green buttons. When the group confirmed that the representation of their observations on the map was complete, we took a digital photo of the map with the buttons. The location of home communities, approximate routes, and vegetation change observations were later digitized in ArcGIS with the help of the digital photos, resulting in a spatially explicit database of observations.

\section{Matrix activity}

Matrix scoring activities are a commonly used instrument in participatory research (e.g., Schoonmaker Freudenberger and

Fig. 2. Illustration of the map activity. (a) Discussion of transhumance with a group of Serer informants. (b) Buttons were used to indicate the locations of the home community (yellow), routes (dark gray), observations of vegetation degradation (red), and rehabilitation/greening (green) on the base map.
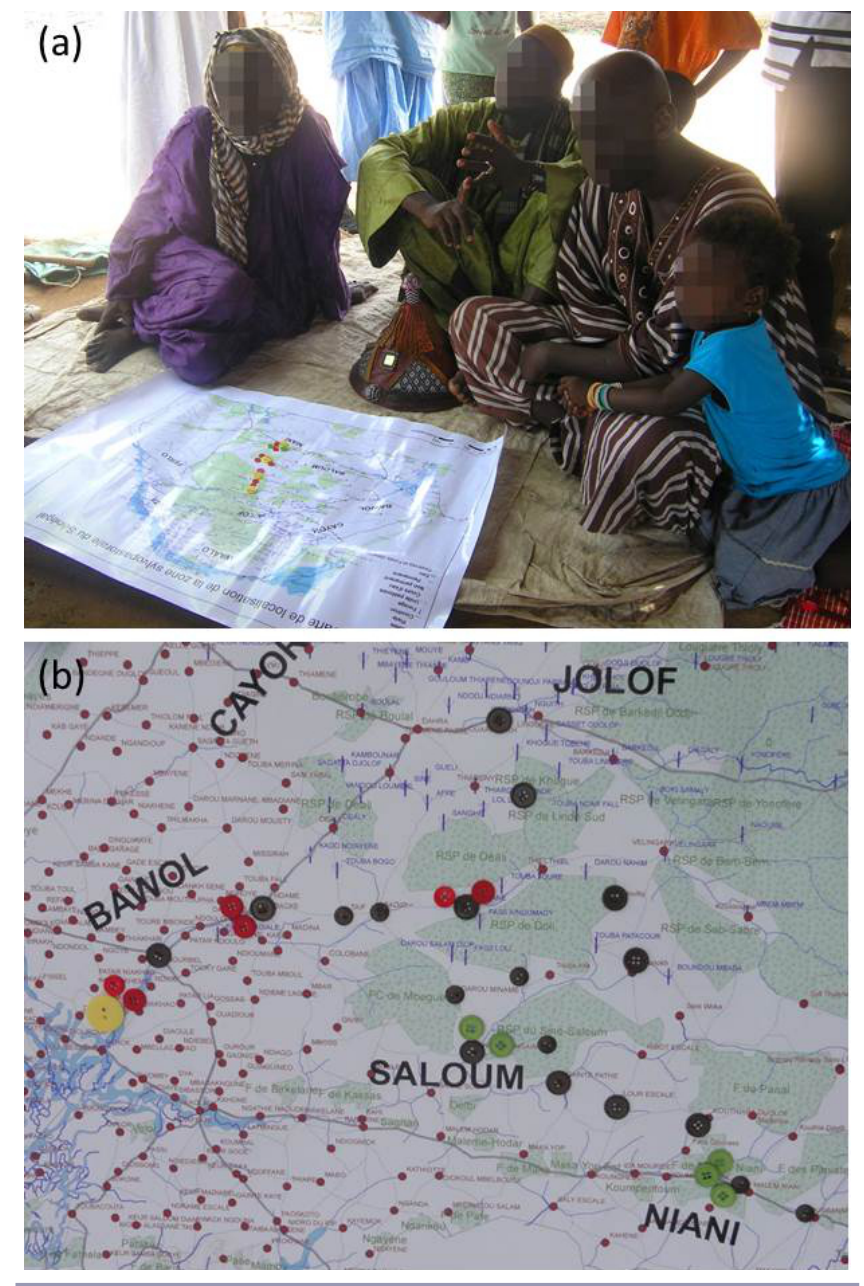

Schoonmaker Freudenberger 1993, Leach et al. 2011). To explore the co-evolution of a number of variables that might be linked to the observed greening trend as either driving forces or impacts, we had each focus group discuss and fill in three two-dimensional thematic matrices, each of which consisted in a set of variables in rows and decadal time periods in columns. Variables and time periods were symbolized with icons to make it easy for everyone to participate in this activity, whether literate or not. For each variable in the matrix, participants represented their recollections of how this variable evolved over time in their home communities by placing a number of buttons in each grid cell, with few buttons meaning that there was little of this variable at a particular time period and many buttons meaning that there was much of this variable (Fig. 3). The number of buttons per grid cell was limited to a maximum of ten. The scores are not to be seen as an accurate quantitative measure; the interest lies more in the evolution of the scores and in the proportions. Another function of this activity, besides generating analyzable semi-quantitative data, was to focus the discussion among the participants on the pertinent themes and to explore the reasoning behind the allocation of scores.

Fig. 3. A matrix of environmental variables (rainfall, water availability, pasture quality, tree densities, and bush fires) filled in by a focus group. Each variable (row) is symbolized by an icon. The five decades (columns) are further visualized by the terms of office of three presidents. The numbers of buttons in each grid cell indicate the magnitude of the respective variable; colors had no meaning in this activity.

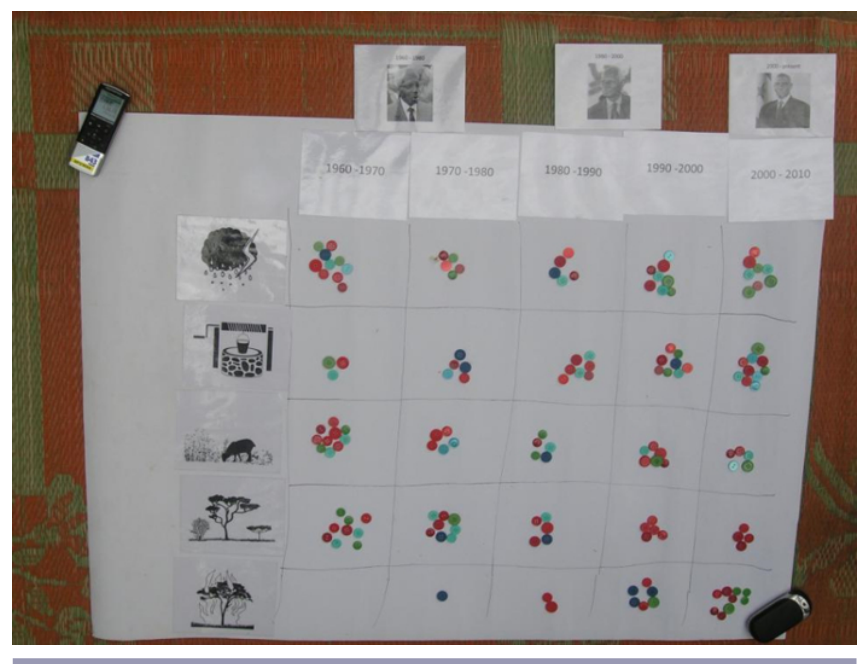

The choice of variables had been inspired by the published literature and prior field trips, which had given us a first indication of potentially relevant issues. The first matrix focused on human and livestock pressures on the environment, as overgrazing and overuse of the vegetation are very commonly cited driving forces for land degradation and desertification (e.g., Sinclair and Fryxell 1985 and other proponents of the equilibrium paradigm, see Herrmann and Hutchinson 2005). The variables included were: (1) human, (2) cattle, (3) small ruminant (i.e., sheep and goat), and (4) camel populations. Rather than speaking of their own families' herds, participants were asked to describe the evolution of the overall amount of each livestock category seen in their home community. 
The second matrix included variables characterizing vegetation and environmental conditions, which could be drivers or effects of degradation and greening. The variables (5) pasture quality and (6) tree densities related to the composition and quality of the vegetation and were meant to complement the greenness information that can be derived from satellite remote sensing. The variable (7) rainfall is considered the most significant climate parameter affecting people's lives as well as ecosystem dynamics in the Sahel (Hulme 2001, Brooks 2004). Scores were to represent the amount of rainfall; however, other characteristics of rainfall were also addressed in the discussions. The scores for (8) water availability were to include water of any source, whether naturally occurring surface water or water accessed through wells and boreholes. Next to fodder, water is an important constraint for livestock rearing and determinant of transhumance routes. The variable (9) frequency of bush fires is of interest because of the potential effect of bush fires on satellite-observed vegetation greenness (Hanan et al. 2008).

The third matrix addressed livelihoods because livelihood conditions are often linked to environmental conditions, as in the case of land degradation having negative economic repercussions (Blaikie 1985, Dahlberg and Blaikie 1999). However, not all livelihood aspects directly involve the use of natural resources. The variables included in this matrix were derived from Frankenberger and McCaston's (1998) household livelihood security concept: (10) food security, here explained as the ease of feeding one's family; (11) education status; (12) health status; (13) the diversity or number of income sources as an indicator of resilience of livelihoods; as well as the number of (14) rich households and (15) poor households in the community.

The matrices included five decades and started with the 1960s, exceeding the AVHRR satellite record by two decades, which provides additional historical context by including the predrought period. To anchor the matrices in space (different evolutions might have taken place in different locations along their transhumance routes), in this activity, we asked the pastoralist focus groups to only speak of their home community as their most permanent reference location. Participants were furthermore instructed to speak for their communities rather than for themselves as individuals. The matrix scores were entered into a database and the discussions recorded.

\section{Data analysis}

\section{Map data}

The map data were analyzed with respect to two objectives: (1) to compare perceptions of degradation and greening among the different focus groups and (2) to compare the perceptions of degradation and greening to the satellite-observed greenness trend. Because the placement of the buttons to denote observations of degradation or greening was approximate, extracting the NDVI greenness trend at the exact location of the buttons would have suggested more precision than possible. Rather, we superimposed a regular grid of $20-\mathrm{km}$ resolution over the study area and averaged the NDVI greenness trend for each grid cell (Fig. 4). We then counted the number of greening and degradation observations in each grid cell as well as the number of different groups by which those observations were made (e.g., one group may have placed three buttons within one grid cell, which would be counted as three in the first count and as one in the second count). Counts and average NDVI greenness trends were superimposed onto one another for visual interpretation of spatial distribution of trends and observations. In addition, the number of observations of greening and degradation, respectively, were plotted against NDVI greenness trends, and linear correlation coefficients were calculated between the two variables (Fig. 5). A buffer of $5 \mathrm{~km}$ around the recorded transhumance routes was used to define the spatial extent of the study area, and grid cells that did not intersect with this buffer were excluded from the correlation analysis.

\section{Matrix data}

The matrix scores describing the perceived evolutions of variables were analyzed by region, assuming that the regions might represent different trajectories of change, as well as by their location inside or outside the area that has significantly greened up according to satellite observations. To summarize the perceived evolutions, the scores for each variable and time period were averaged by region (Figs. 6-8). The perceived evolutions were also summarized by extracting the perceived directions and magnitudes of changes in the form of the slopes of linear regressions of the scores against time. The slopes (or trends) of each variable were then averaged in two groups: those that fall into the greening area (greening communities) and those that fall outside of it (nongreening communities). A t-test was performed to test whether differences between the two groups were statistically significant (Fig. 9). The transcripts of the discussions accompanying the matrix activity were analyzed for themes that occurred frequently in the reasoning behind the scores.

\section{RESULTS AND DISCUSSION}

Perceptions of vegetation improvement and degradation and their comparison with NDVI trends

A set of maps illustrates the spatial distribution of perceived degradation (Fig. 4a) and improvement (Fig. 4b) of the vegetation cover along transhumants' routes. Degradation observations are clustered in the central to western part of the study area, whereas improvement was observed primarily in the center and east. The overlay of both degradation and improvement layers (Fig. 4c) shows that in several grid cells, both degradation and improvement were reported. This is not surprising because phenomena of degradation and rehabilitation of the vegetation often happen at much finer scales than this coarse grid. Moreover, despite our efforts to keep explanations uniform, different groups might focus on different aspects of improvement and degradation (Warren 2002).

The spatial concentration of observations of vegetation improvement in the central part of the study area corresponds to some of the largest increases in NDVI. However, the concentration of observations can also be explained by the convergence of transhumance routes passing through the center (Fig. 1). There were, therefore, more focus groups who could potentially report ground observations for these areas than for the edges of the study area, where fewer groups traveled.

A total of 146 degradation observations were reported compared to only 84 observations of improvement of the vegetation cover, which indicates that degradation clearly dominates people's perceptions. By contrast, the satellite observations show mostly positive trends in NDVI (Fig. 4d), which indicate an increase in 
Fig. 4. Spatial representation of people's perceptions of changes in vegetation cover and NDVI trends (by $20 \times$ $20 \mathrm{~km}$ grid cells). (a) Number of focus groups reporting observations of degradation of the vegetation cover. (b) Number of focus groups reporting observations of rehabilitation/improvement of the vegetation cover. (c) Observations of degradation and improvement combined. (d) NDVI trends for 1982-2008 at the original $8 \times 8$ $\mathrm{km}$ resolution. (e) Observations superimposed on NDVI trends averaged for $20 \times 20 \mathrm{~km}$ grid cells. Gray grid cells represent the area of Senegal that was not crossed by any of the mapped routes of transhumance and was hence excluded from the analysis.

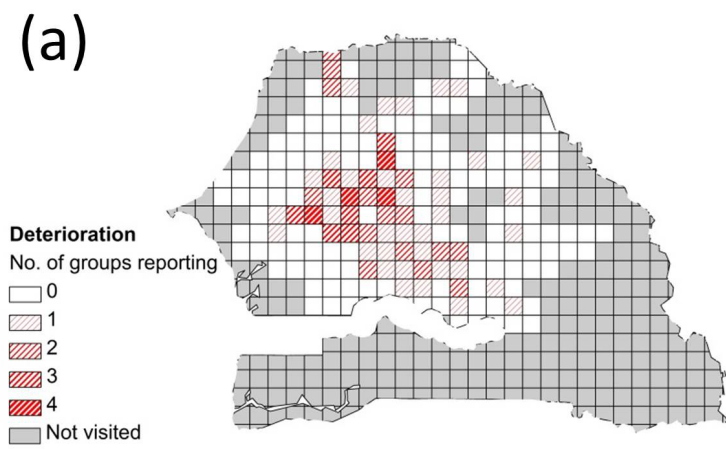

(c)
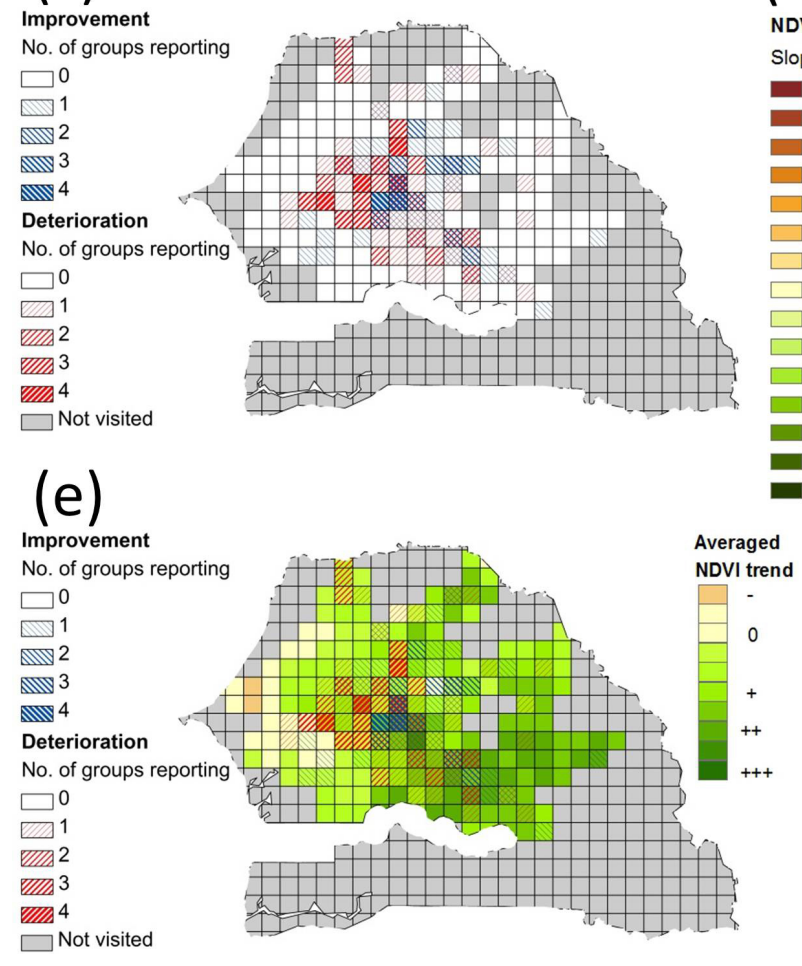

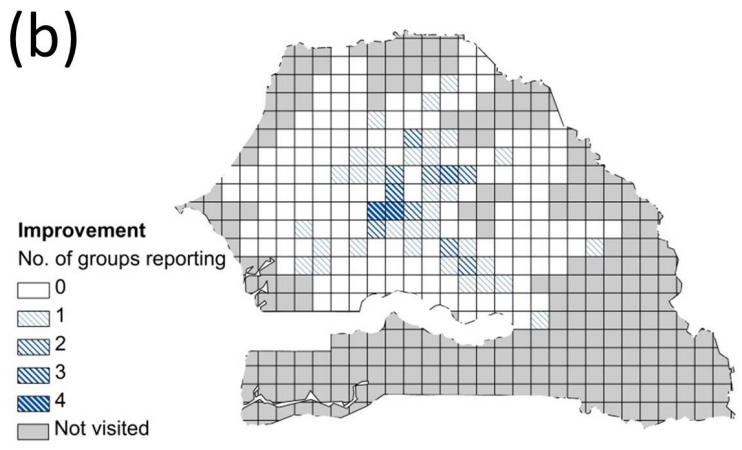

(d)

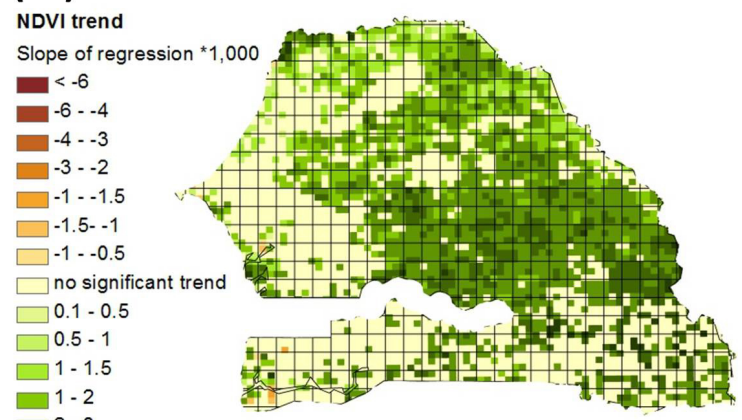

$4-6$ bioproductivity. The strongest positive trends are located in the central and eastern part of the study area, which corresponds to the mostly pastoral regions of Senegal, where vegetation cover is dominated by woody savanna. In the predominantly agricultural regions to the west, trends in NDVI are insignificant. This eastwest gradient is to some degree confirmed by our informants, who have not observed any rehabilitation of the vegetation in the western agricultural regions (Fig. 4e).

The correspondence between people's observations and the satellite-derived greening trend is further illustrated by two- dimensional scatterplots contrasting the number of ground observations of degradation or greening reported in a particular grid cell and the mean NDVI trend of that grid cell (Fig. 5). For the greening observations, there is a positive relationship between the number of observations in the upper envelope and the magnitude of the NDVI trend (Fig. 5a). Grid cells with many greening observations are characterized by high NDVI trends. Not all grid cells with high NDVI trends, however, accumulated many greening observations. This can be explained at least partly by the fact that some grid cells were crossed by more transhumant 
Fig. 5. Scatterplots indicating the correlation of transhumants' perceptions of improvement or degradation of vegetaton with the remote sensing observations of trends in NDVI. (a) Geening/improvement of vegetation cover. (b) Degradation of vegetation cover. The NDVI is a unitless measure of vegetation greenness. Trends in NDVI (x-axes) are the slopes of the linear regression rescaled by 1000 .
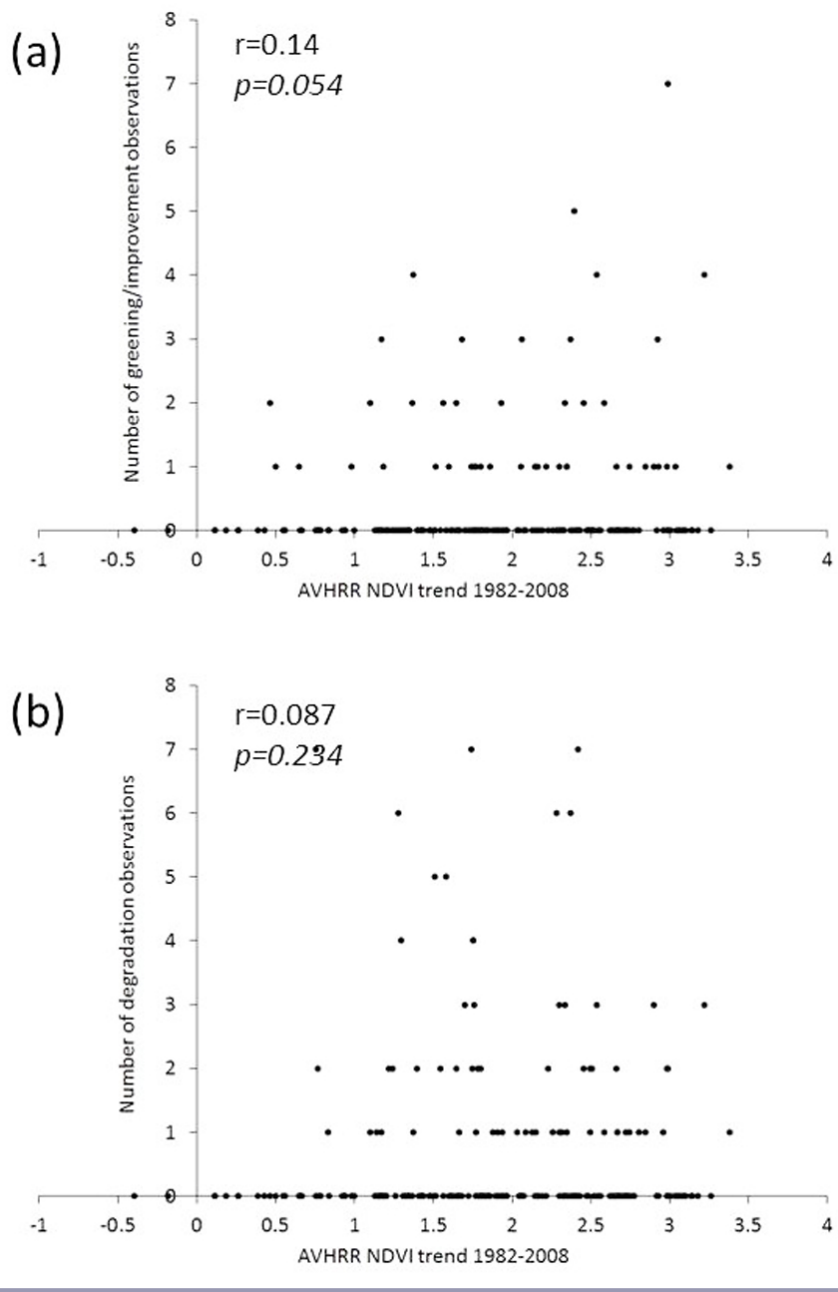

groups than others. Three-quarters of the grid cells that were crossed by at least one group reported no observations of either greening or degradation, and they cover the whole spectrum from weak to strong NDVI trends. Despite those outliers (cells that reported no observations of either greening or degradation), the relatively low correlation coefficient (Pearson's $R$ ) of 0.14 is significant with $P=0.054$.

By contrast, there is no significant relationship between observations of vegetation degradation and magnitude of NDVI trend (Fig. 5b). Some grid cells with strong positive NDVI trends even accrued a few observations of vegetation degradation. Only one grid cell has a very weak negative NDVI trend indicating a decrease in bioproductivity. As observed by our transhumant informants, degradation can nonetheless be present in the study area, but occur at smaller spatial scales and be masked by the
Fig. 6. Perceptions (average matrix scores) of the evolution of tree densities (a) and pasture quality (b) from the 1960s to the 2000 s, averaged by region.

(a)

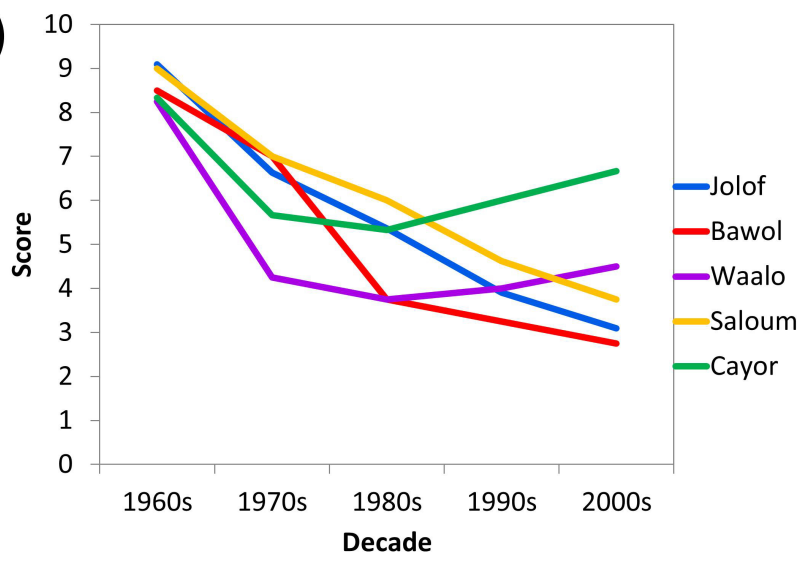

(b)

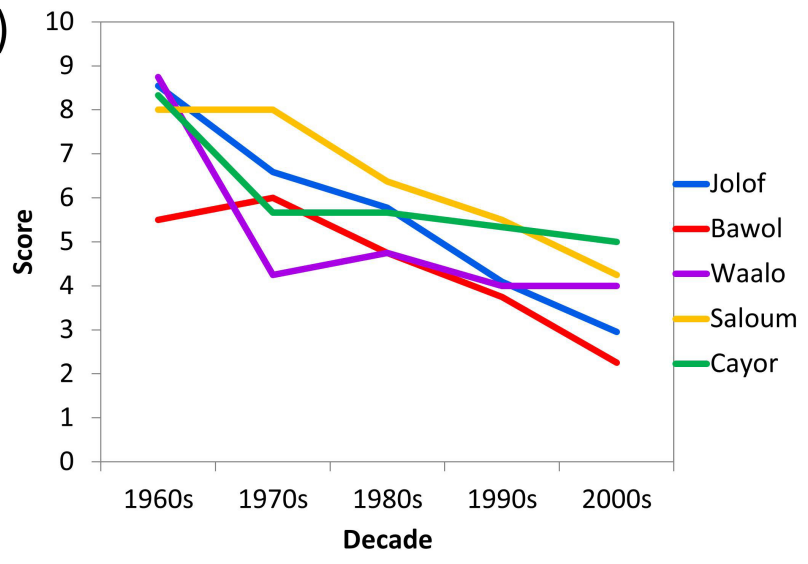

Fig. 7. Perceptions (average matrix scores) of the evolution of rainfall amounts from the 1960 s to the 2000 s, averaged by region.

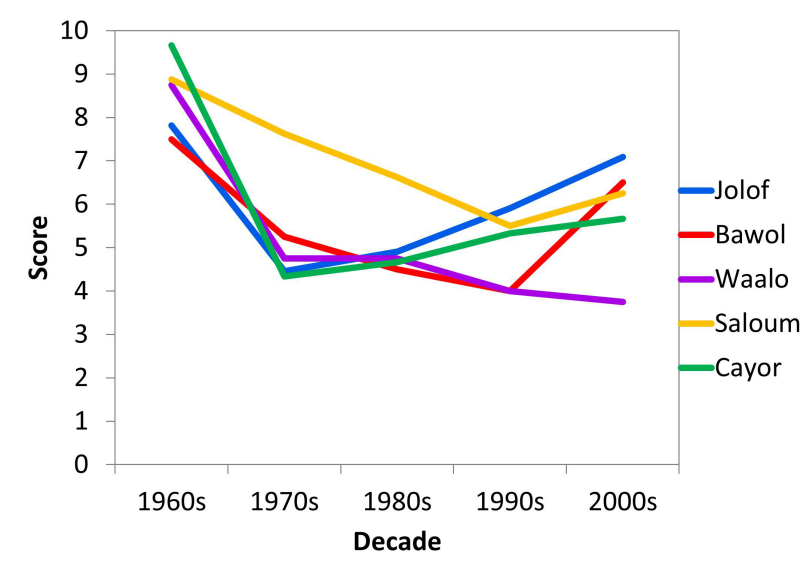


Fig. 8. Perceptions (average matrix scores) of the evolution of cattle (a) and small ruminant (b) populations from the 1960s to the 2000 s, averaged by region.
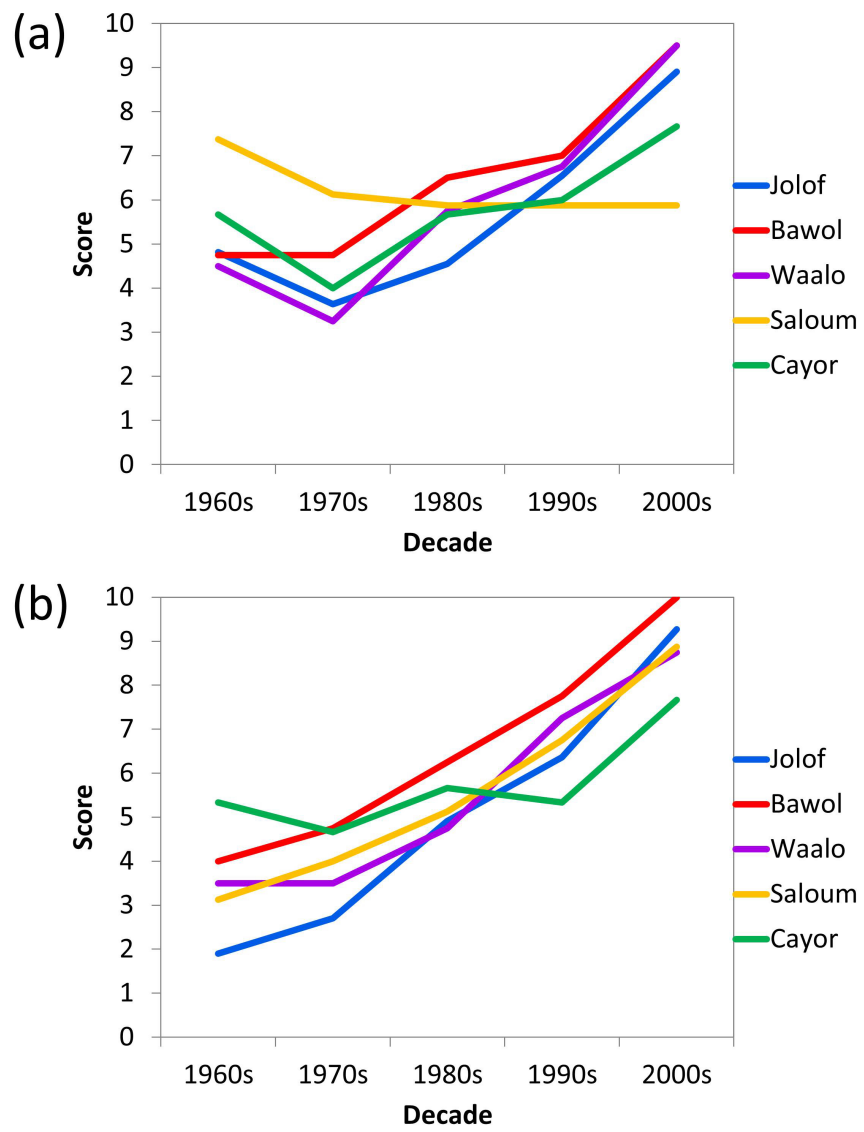

overall rainfall-driven increase in herbaceous vegetation cover (Herrmann et al. 2005). The discrepancy between people's perceptions of degradation and the predominance of positive NDVI trends might also be explained by the difference between quantity and quality of biomass. The NDVI does not differentiate between types and species of green vegetation, whereas for land users, the composition of woody and herbaceous vegetation, annual and perennial grasses, and woody vegetation species are important indicators of the status of vegetation degradation. Stable or even increasing bioproductivity can accompany an impoverishment of the vegetation and be interpreted as degradation (Herrmann and Tappan 2013).

\section{Perceptions of the evolution of environmental variables}

\section{Vegetation}

The matrix activity yielded more in-depth information on environmental changes that took place in the home communities of the informants since the 1960s. The variables "tree densities" and "pasture quality" both describe the quality of green, which is not captured by the NDVI.

The perceived evolution of tree densities varied slightly among different groups from different regions but has been overwhelmingly negative (Fig. 6). Trees were reported to have decreased almost everywhere, with some exceptions where trees were explicitly protected through public and private efforts and have regenerated. However, the trees that regenerated naturally belong to only a few drought-tolerant species, with species diversity decreasing despite this regeneration. As a villager from the Jolof put it, "In 1990, traveling here [Barkedji] from Pate Wuro, you could find trees without thorns, but nowadays you can only see patouki (Acacia senegal), mourtoki (Balanites aegyptiaca), and other thorny trees here, which were not there before. This has happened since the transhumants came into the area in 1973. Wherever their livestock spent a night, new [thorny] trees appeared and other trees died." Another focus group confirmed that certain trees "cannot coexist with animals and people." The loss of trees has been felt by informants in all regions. One informant from the Saloum recalled, "In my fields, there used to be more than 30 kinds of trees. Now there are only four left." Whereas the loss of trees is almost ubiquitous throughout the study area, the explanations differ slightly. In the Bawol, Cayor, and Saloum regions, expansion of agriculture was mostly held responsible for the disappearance of trees. Cutting of trees for firewood and charcoal-making as well as drought effects on trees were mentioned in the Jolof and Saloum regions. Drought can be a direct driver of tree loss by affecting the water supply of the tree to the point that the tree dies, as well as an indirect driver, when drought results in insufficient herbaceous pasture and forces pastoralists to lop tree branches as browse for their livestock.

Some of the tree species that were most frequently mentioned to have decreased or disappeared from the informants' home communities include Acacia seyal, Terminalia avicennioides, Dichrostachys cinerea, Sclerocaria birrea, Grewia bicolor, Sterculia setigera, Guiera senegalensis (Jolof), Feretia apondanthera (Jolof), Tamarindus indica (Jolof), Gardenia ternifolia (Saloum), Cordyla pinnata (Saloum), Bombax costatum (Saloum), and Anogeissus leiocarpus (Saloum). Many of those trees are sought after for their fruits, leaves, or wood. Although some older individuals of these species are still found, people observed a lack of regeneration of young individuals.

While losses in tree cover dominated people's perceptions, some focus groups saw increasing tree densities in their home communities; those increases, however, were limited to a few species. One tree species that was perceived to have increased throughout the whole region is Azadirachta indica (also known as the neem tree), a non-native tree originating from India and commonly planted as a shade tree in villages. The droughttolerant Balanites aegyptiaca was perceived to have expanded mostly in the Jolof region. In individual communities, plantations have led to very localized increases in tree densities such as Jatropha curcas (Cayor), Acacia senegal (gum Arabic; Waalo), and fruit trees, including mango and citrus varieties (Cayor and Bawol), whereas at the same time, savanna trees were found to have decreased in number and diversity. The observed impoverishment of tree cover confirms findings by Herrmann and Tappan (2013) for the Saloum region. It is also in line with findings by Gonzalez (2001) for northwest Senegal, as well as Lykke (1998) and Sop and Oldeland (2013) for northern Burkina Faso. 
Fig. 9. Trends in matrix scores of 15 variables over three decades averaged by greening communities and nongreening communities. The $P$-value is a measure of significance of the difference between the greening and nongreening communities. $P<0.1(0.2)$ is considered statistically significant at a $90 \%(80 \%)$ probability level.

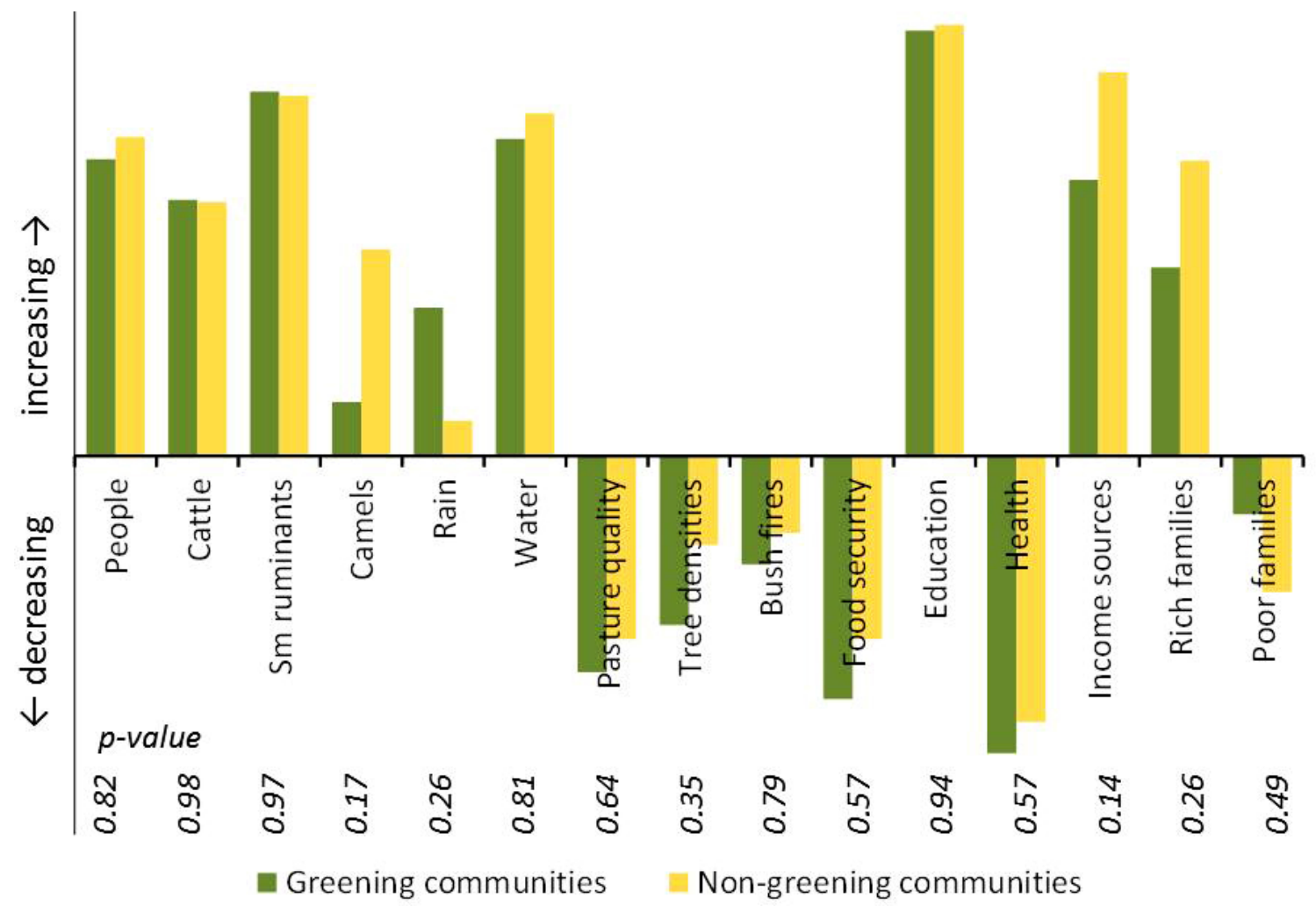

Changes have also been seen in the quality of the herbaceous pasture, which has been declining steadily according to most focus groups, judged by the nutritional status of the animals and their ability to produce milk. As one informant from the Cayor region stated, "With the rains improving, there is more grass now, but our animals still do not produce as much milk as they did in the past, so the quality of the pasture must have deteriorated." Particularly dengo (Zornia glochidiata), a grass favored by sheep, has become rare in the home communities of many of the informants. Other grasses mentioned that are declining include guirngal (Blepharis linariifolia), gourdoungal (Borreria filifolia), and paggiri (Panicum laetum). In contrast, new species have appeared, which are lower in the utility preferences of the informants, including kebbe (Cenchrus biflorus) and a red herb (Cenchrus ciliaris) in the Jolof, as well as selloute (could not be identified) and gnakhou waalo ("grass from the Waalo") in the Saloum.

While there was general agreement that the initial strong decrease in pasture quality was linked to the droughts of the 1970s, three reasons for the continued decline despite a recovery of the rains came up repeatedly in the discussions. First, the prolonged droughts favored the proliferation of herbaceous species that are more drought tolerant but less nutritious to the animals. The species of higher fodder value, which were common in the 1960s, have decreased or disappeared. As a result, even when there appears to be an abundance of green, the quality of the pasture is not necessarily good. Only a minority of the focus groups reported improvement in pasture quality that paralleled the increase in rainfall in recent years. Second, the temporal distribution of rainfall plays a role for pasture quality, and it has shifted unfavorably. Once the pasture reaches a point of maturity and begins to dry, any additional rain is detrimental to its quality, which explains why the increased rainfall of the last decade has not contributed to an improvement in pasture quality. Third, the ever-growing presence of people and their herds has deteriorated pastures because of increased grazing pressure and trampling. Moreover, some people harvest the preferred pasture herbs to sell them on the market, which has become a lucrative income opportunity. Shortages of pasture occur in the densely populated and intensely cultivated areas of the Bawol and Cayor regions, as well as in the outskirts of large towns, which forces pastoralists to either buy supplements or go on transhumance.

Local land users' observations of changes in the vegetation cover support the nonequilibrium thinking of the panarchy theory and the DDP: Prolonged droughts were seen to have shifted the vegetation cover across a threshold to a new stable state, with a more drought-tolerant pasture composition. The observations are also in line with the phenomenon of "green desertification", a degradation in vegetation quality accompanied by an increase in biomass, which was documented in the literature of the 1980s (e.g., Helldén 1984, 1988, Olsson 1985, and Ahlcrona 1988, all cited in Warren and Agnew 1988), but has so far received 
insufficient attention or ground evidence in the more recent greening debate.

\section{Rainfall}

Rainfall is the most limiting factor to vegetation growth in the Sahel, and hence, is an important variable in the discussion about degradation and re-greening/rehabilitation. In accordance with measured station data (Dai et al. 2004, Nicholson 2013), the 1960s were generally perceived to have had the most abundant rainfall compared to the following decades. Many focus groups indicated a sharp drop in rainfall in the 1970s. In particular, the year 1973 stands out in the memory of every Sahelian as a catastrophic year across the entire region, with devastating losses in livestock and human life (Batterbury and Warren 2001, Mortimore and Adams 2001). Although the majority of groups saw the 1970 s as the worst decade in terms of rainfall, some argued that the 1980s were overall worse than the 1970s; however, the populations were better prepared to deal with the drought and hence the impacts were less severe. There was less agreement about the evolution of rainfall in the 1980 s to 2000 s, with some observing a recovery of the rains but not necessarily reaching pre-drought levels, and others perceiving continuously low or declining rainfall. The majority of focus groups from the Saloum perceived the 2000s as the worst decade in terms of rainfall amounts, whereas more than one-third of the groups from the Jolof thought that decade was better than or equal to the $1960 \mathrm{~s}$.

Scientific analyses agree that the 1970s and 1980s were markedly drier than the two previous decades across the Sahel region. Rainfall conditions after 1990 have received less scientific attention, partly due to the difficulty of obtaining rain gauge data in the more recent past, and have given rise to more disagreement, not unlike the views of our informants. Some scientists postulate that the regional drought continued through the 1990s; others show a recovery of rainfall since the 1980 s, with some very wet years interrupted by a few dry years (Nicholson 2013).

While the question referred to rainfall amounts, there are other characteristics of rainfall that are also important for both farming and pasture quality, in particular, the temporal distribution of rainfall events. According to our informants, the latter has changed unfavorably despite the recent recovery of rainfall amounts, with delays in the onset of the rainy season and fewer but heavier rainfall events. While rainfall always spurs biomass production, too much rain at the wrong time can damage the quality of the vegetation, whether crops or pasture. Scientific research has confirmed the increasing interannual variability of rainfall, decreasing number of rainfall events, and simultaneously increasing intensities since the 1960s, as well as shifts in the onset and cessation of the rainy season throughout the Sahel (Ali and Lebel 2009) and in Senegal (Salack et al. 2011). The negative effects of these changes in rainfall characteristics on development and yield of agricultural crops might have influenced the perceptions of rainfall amounts, particularly of focus groups from communities where farming played a large role.

\section{Water availability}

There was almost unequivocal agreement that the water availability for household and livestock use has improved steadily over the decades, irrespective of perceived trends in rainfall. This improvement can largely be explained by the increase in wells and boreholes, which made households and communities independent from surface water. Particularly in the Jolof, which had traditionally been used as rainy season pasture only, boreholes have been installed since the end of the colonial period and their numbers have increased tremendously, enabling the presence of livestock year-round, with potential effects on vegetation cover (Sy 2003).

By contrast, surface water was reported to have been more available in the 1960s, when rainfall was most abundant. In the Saloum, temporary ponds would last until December or January, whereas today they are already dried up by October, forcing transhumants and their herds to the boreholes, which locally increases the grazing pressure and has been a source of conflict between the autochthone population and the transhumants. Although NDVI gradients around boreholes provided no clear evidence of decreasing biomass quantities under increasing grazing pressure according to other studies (Hanan et al. 1991, Lind et al. 2003), degradation in the form of unfavorable changes in vegetation composition (i.e., increase in unpalatable species, loss of biodiversity) could still be taking place, as shown by Miehe et al. (2010) for a site in northern Senegal.

While water is now more widely available than it was in the past, as the network of boreholes and watering points has become denser, problems of accessibility because of the cost of water were mentioned several times. Until the 1980s, boreholes had been managed by the state, and water was provided for free. With the privatization of boreholes, water prices have gone up (Sy 2010). The improved water availability has another downside, which some of the focus groups and certainly our key informants are aware of: the ground water tables have dropped in some areas as a result of overdrafting, and one focus group from the Cayor region reported that some shallow wells have already fallen dry, reminding land users that water remains a limited resource despite its improved availability.

\section{Bush fires}

The evolution of the frequency of bush fires was perceived differently by different groups and in different regions, though the overall observed trend was one of decrease. In the heavily cultivated areas of the Bawol and Cayor regions, bush fires decreased because the expansion of farming and the livestock pressure on the remaining patches of savanna have reduced the available fuel. Some focus groups in the Jolof region observed an increase in bush fires in their communities, whereas others noted a decrease, which they ascribe to successful sensibilization of the population and the establishment of fire alert systems and volunteer brigades. The informants generally regarded fires as negative because, when uncontrolled, they can lead to losses of fodder in both the herbaceous and woody vegetation strata; however, used as a management tool early in the dry season, fire could benefit the pastures by promoting nutrient-rich regrowth (Mbow et al. 2000).

\section{Perceptions of the evolution of population and livestock pressure}

Changes in human population and livestock numbers were frequently mentioned as one of the drivers behind changes in environmental variables, particularly the vegetation. All but three focus groups observed a steep upward trend in the population in their communities. The population growth is characterized as exponential, with one informant recalling, "every village that had one household [in the 1960s] now has ten." This is in line with the 
official population statistics for Senegal, a country characterized by its youth and rapid growth owing to high levels of fertility, whose population has quadrupled since 1960 (Food and Agriculture Organization 2013). However, internal migration, particularly directed to the urban centers, has made the population grow faster in some places than in others. Particularly, the urban agglomeration of Touba has grown rapidly, the pressure of which has been felt by the focus groups from its vicinity, who noticed the effects of fuel wood and hay collection on the vegetation cover in their communities.

The three focus groups that indicated a loss in population since the 1960 s represent communities where out-migration has taken place due to adverse environmental and economic conditions in the communities. The informants explained that lack of rainfall and loss of soil fertility have rendered farming unviable and pushed people to leave their communities in search of better opportunities elsewhere.

Livestock herds were also perceived to have increased since the 1960s. The scores for cattle (Fig. 8a) show a noticeable drop in the 1970s, which reflects the high mortality during the drought years. The effect of the drought on livestock was acknowledged by all focus groups; some groups, however, felt that the drought did not affect the entire decade because cattle herds were being rebuilt already by the late 1970 s. Not only were herds rebuilt within a decade after the drought-induced losses, but they soon exceeded their pre-drought levels. Partly, this is explained by societal changes that took place: In the past, cattle ownership had been the privilege of a kilife (man of importance and means, usually an elder); today, every household has their own herd, and with the expansion of nuclear families, there are more and more cattle herds. According to the informants, the development of a denser network of watering points in the Jolof region also contributed to the increase in cattle there.

Whereas cattle numbers were generally reported to be on the rise, which is also confirmed by official estimates (Food and Agriculture Organization 2013), downward trends in cattle numbers were observed by five of eight focus groups from communities in the Saloum region. The reasons for this decrease were given as lack of pasture due to expansion of agriculture and preference for small ruminants (i.e., sheep and goats), which multiply faster and provide better economic benefits than cattle. Indeed, the number of small ruminants was perceived to have increased across all regions, particularly in the 1990s and 2000s, as people became aware of the income and market opportunities with sheep (see also Adriansen 2006, 2008). Particularly, the Saloum region is seen as a fertile ground for sheep because the pasture composition is favorable for small ruminants; hence, it has become a destination for transhumance of sheep herds from the Waalo and Jolof.

While some of the informants from the Saloum region reported to have turned away from cattle as a result of their focus on small ruminants, informants from the Jolof, traditionally a cattle region, said that the growing importance of small ruminants has allowed their cattle herds to grow even more. "Today, the cattle are considered as the savings account; they are set aside and not consumed or sold. This is what the sheep are for," a Peulh informant from Jolof said. Held back from selling, cattle are accumulated as a status symbol. The trend toward herd diversification can be seen across regions and ethnic groups. For example, in the Cayor region, only the Peulh had kept cattle in the 1960 s, but after the drought, cattle sold very cheaply, so the Wolof started buying cattle and raising it themselves. In the traditionally cattle-dominated Jolof region, the local Peulh became inspired to raise sheep by observing the passing Serer transhumants.

Most focus groups expressed concern about the impacts of increasing livestock herds on the vegetation cover. Whereas cattle can cause damage due to their body mass and feet, sheep sweep an area systematically, can get to the very short grass by kneeling down, and leave nothing behind, exposing the soil to erosion. Perceived as most notorious for their degrading impacts, however, were camels, which were observed in only a few of the informants' communities. In addition to their feeding on practically any vegetation, including browsing on tall trees, their presence was associated with the proliferation of thorny trees and livestock diseases.

\section{Perceptions of the evolution of livelihoods and well-being}

Discussions and recollections of the evolution of livelihoods and well-being were complex and somewhat contradictory among focus groups, given the more subjective character of some of the variables. A vast majority of groups $(>80 \%)$ found that it was easier to feed one's family in the 1960s and that it has gradually become more difficult since then, despite more food items having become available on the market. However, the rising cost of food prompted the informants to attribute decreasing scores to food security over time. In the 1960s, people were better able to subsist on what they produced. "In the past, a father could feed his family with what he harvested and with the milk from his livestock, and go for a whole week without having to go to the store. Even when he had guests, he could feed them without spending any money," explained an informant from the Jolof. Another informant from the Saloum remembered, "Children could find something edible in the bush, and when they came back home, their stomachs were already full and they only had to be given some milk." During the droughts of the 1970s, it became difficult to feed one's family because harvests failed, livestock died, and the markets were empty. However, the government provided food aid, which eased the situation. Nowadays, the markets are well stocked, but food is very expensive. Tree products and wild animals, which supplemented the diet in the past, have become scarce as a result of overuse. The quantity of harvest has improved since the drought but is still inferior to that of the 1960s. Government subsidies have been discontinued. At the same time, there are more mouths to feed, so the situation is perceived as getting progressively more difficult. This view was rather consistent among the focus groups, with the exception of a couple of groups from the Cayor region, where gardening activities have made an important contribution to nutrition since the 1990s. With eating habits changing away from locally produced grains to more processed foods, the health status of the population was widely perceived as degrading, despite improvements in the health infrastructure.

While there was broad agreement on the negative evolutions of the food security and health variables, the perceptions of the informants somewhat contrast with a number of country-wide indicators published by the World Bank (World Bank 2013). 
Though inconsistent in chronology (the series contains different beginnings and some gaps), these indicators reveal more positive developments: for example, the prevalence of undernourishment in the population has decreased since 1990, particularly between 1995 and 2005, after which a slight increase was recorded; this slight increase, however, does not reach the levels of the mid-1990s. People's perceptions seemed to pick up on the more recent difficulties, without taking into account longer term improvements.

There was wide agreement on improvements in the education status of the population, which confirms country-wide figures on increases in primary school enrollment from $41 \%$ in 1971 to $86 \%$ in 2011 , with the enrollment of girls increasing from $32 \%$ to $89 \%$ over the same time period (World Bank 2013). Income opportunities have expanded from farming and livestock rearing to include livestock fattening and trade, retail businesses, transportation, crafts, employment in publicly and privately funded projects, salaried work in cities, and remittances from emigration abroad. The diversification of income strategies was reported to have resulted from necessity as well as opportunity: The difficulties of subsistence agriculture experienced with the drought crisis forced people to look for alternative income opportunities, and the improved level of education opened new doors.

According to the informants, the increasing number of income opportunities has brought some wealth into their communities, despite the hardships that they are still facing. Eighty percent of the focus groups indicated an increasing number of well-to-do households in their communities. They are eager to stress however that this is not because the living conditions have become easier, but because people have become more aware of how to make a living. Unlike in the past, when only some elders might have had acquired some wealth in the course of their lifetime, material assets resulting from emigration and better education can be found among the young today. Pointing at a teenager, one informant remarked, "The very young are already looking for wealth. Even this kid knows of different ways of making money." One focus group in the Bawol observed, "There are more rich families in our community now. They bought back houses that only the Maurs [Mauritanians of Arab descent, who dominate the small retail trade in northern Senegal] could afford before. Nowadays, the locals own many things that only the Maurs had before." In other regions as well, it was noticed that more families can afford to build solid houses. Livestock holdings have generally increased. "Those who have more than 100 sheep or more than 100 heads of cattle have become so many that we cannot count them anymore," observed an informant from the Waalo region. However, almost one-third of the focus groups saw poverty increasing in their communities at the same time. A growing lack of solidarity among people and absence of government aid were mentioned several times to explain this trend. Although not the predominant view, some informants experienced a loss of income opportunities associated with the degradation of the environment, such as a lack of tree products, which they used to be able to collect and sell on the market.

\section{Discussion of perceived evolutions in the context of greening} A comparison of the temporal trends from 1980 to 2010 in perceptions of the 15 variables averaged for the communities located within the area of significant satellite-observed greening with those averaged for the communities located outside the area of significant satellite-observed greening showed no differences in the direction of trends between both groups and no statistically significant differences $(P<0.1)$ in the magnitude of the trends (Fig. 9). This lack of statistically significant differences at the $90 \%$ probability level is also due to high within-group variability.

Not surprisingly, population and livestock numbers were perceived to have increased across all communities, whether located in a greening area or not. Only the camel populations increased considerably more in the nongreening communities than in the greening communities. The discussions revealed that camels were seen as most damaging to the vegetation cover; however, their overall populations are small and they were present in only half of the communities. From our analysis of people's perceptions, it appears that the discrepancy between satelliteobserved greening and nongreening cannot be explained by differences in the evolutions of grazing pressures.

Rainfall amounts were perceived to have improved more in the greening communities than in the nongreening communities, which is consistent with the rainfall-driven greening postulated by Hickler et al. (2005) and provides additional evidence of the important role of rainfall in increasing the NDVI. It has to be noted, though, that the perceived increases in rainfall over the last three decades constitute a reversal of perceptions compared to the perceived negative evolution of rainfall over five decades.

Water availability was perceived to have increased over the study area as a result of improved water infrastructure, with no significant difference between the greening and nongreening communities. The more ubiquitous water availability allows for more dispersed grazing and use of remote pastures. According to the informants, it also contributed to changes in herd composition and transhumance patterns. These changes, however, do not appear to be reflected in the greening trends.

The quality of vegetation cover was perceived to have decreased, with negative trends in both pasture quality and tree densities. This does not necessarily contradict the satellite-observed greening trend, but further describes the quality of that trend (Herrmann and Tappan 2013). In the nongreening communities, trees have decreased less steeply, which might be a result of there having been fewer trees in the first place, as some of the nongreening communities have been heavily cultivated for decades with little natural savanna vegetation left.

Perceptions of bush fire frequencies varied, although a slight decrease was perceived on average. The relationship between fires and biomass is complex (Hanan et al. 2008). However, less burned area, which depresses the NDVI, could translate into a greening trend.

According to the analysis of people's perceptions, the greening does not seem to have engendered any improvements in wellbeing. Food security was perceived to have deteriorated over time, even more so in the greening communities than in the nongreening communities. This seems to contradict somewhat the perceived increases in income opportunities and in rich households in the communities. The latter two show considerably steeper positive trends in the nongreening communities than in the greening communities, possibly pointing to greater diversification of 
income opportunities away from pastoralism and farming in locations where the vegetation productivity has evolved in less favorable ways, resulting in a decoupling of livelihood strategies from the vegetation resources (Nielsen and Reenberg 2010, Murzabekov et al. unpublished manuscript).

In summary, most developments indicated by the informants seem to be unrelated to the increase in bioproductivity suggested by coarse-resolution NDVI data since the 1980s. Of the variables that were included in the activities because of their potential as explanatory factors of the greening, only livestock pressure from camels and rainfall amounts were perceived to have evolved differently between the greening and nongreening communities. In terms of livelihoods and well-being, the nongreening communities appear to have fared slightly better than the greening communities, which disproves the idea of positive effects of the greening trend. Following an inverse reasoning, it could also be speculated that wealth in the nongreening communities has been generated in environmentally unsustainable ways, resulting in a lack of recovery of bioproductivity.

\section{Discussion of limitations and uncertainties}

The two sources of observational data we combined in this analysis, i.e., coarse-resolution satellite data and environmental observations made by local land users on the ground, both have some limitations associated with them, which result in uncertainties in their interpretations. The AVHRR NDVI data, while providing the longest continuous record of satelliteobserved greenness available and being widely used and accepted, is not only coarse in resolution, with a pixel size of $8 \times 8 \mathrm{~km}$, but also poor in locational precision. This poor locational precision results from the on-board processing of data forced by the needs of data compression, which samples subsets of originally higher resolution $(1.1 \mathrm{~km})$ pixels and averages them to derive the $8-\mathrm{km}$ data (Justice et al. 1989, James and Kalluri 1994). Further limitations of interpreting the NDVI trends as land degradation or improvement arise from the fact that the linear trends do not capture more complex temporal patterns of greening and browning that might have occurred at different periods of the data record. Thus, very recent losses in bioproductivity could be hidden by an overall increase in bioproductivity at longer time scales, and vice versa.

Uncertainties can also be found in the observational data gleaned from local land users. Not unlike the NDVI, the observations on changes in vegetation cover made by transhumants along their routes are characterized by rather coarse spatial precision, forcing us to work at a lower grid resolution. Certain limitations are inherent in the participatory research methodology (Pain 2004): While focus group participants were encouraged to speak for their communities rather than for themselves as individuals, communities are heterogeneous in their perceptions, and not all perceptions could be represented equally. The two participatory activities focused on group consensus rather than diversity of perceptions, which could have been dominated by the most vocal participants of each group. In addition to such representational bias, memory bias might have been present in three ways. First, our research focused on long time scales; however, people tend to remember the recent past more accurately than the more distant past. Second, characterizing environmental change in decadal time intervals is challenging, given the variability of conditions, and people's awareness of this variability, at shorter time intervals. Third, people tend to view the past in a more positive light than the present, which could have biased perceptions of environmental change toward negative changes. It furthermore has to be acknowledged that expectations of a desired outcome, such as receiving aid for the problems they identified, could have influenced the focus group discussions, despite our emphasizing that the purpose of the study was to generate knowledge only.

\section{CONCLUSIONS}

We used participatory activities to encourage discussion and capture the perceptions of local land users on the evolutions of their natural environment and livelihoods at a sub-regional scale. We compared and contrasted those perceptions with findings from time-series analysis of coarse-resolution NDVI data, which suggested a greening trend in part of the study area. Our findings challenge the prevailing chain of assumptions of the satelliteobserved greening trend indicating an improvement in environmental conditions in the sense of a rehabilitation of the vegetation cover after the great droughts of the 1970s and 1980s, and the improvement of environmental conditions possibly translating into more stable livelihoods and greater well-being of the populations.

Our analyses show no strong spatial correlation between the satellite-observed trends and perceived environmental conditions. On the one hand, the informants confirmed an increase in biomass in some of the areas where satellite data indicate a significant greening trend. On the other hand, observations of vegetation degradation, which were reported more frequently than improvement, conflict with satellite-observed trends. Even in locations where bioproductivity has reportedly increased, this increase was not automatically linked to an improvement in the quality of the vegetation cover, indicating that caution has to be used when interpreting NDVI trends in terms of land degradation and rehabilitation.

Local land users observed increasing population and livestock pressure over the past five decades and mostly deteriorating environmental conditions, particularly when compared to the predrought (1960s) baseline. Despite the prevailing deterioration of the environment, expressed as loss of trees, degrading pasture quality, and unfavorable rainfall distribution, livelihood conditions and well-being were not overall perceived as getting worse. On the contrary, a number of variables were seen to have improved over time, including the diversification of income opportunities, some of which are less directly dependent on environmental conditions and were pursued as adaptation strategies to the environmental crisis. People are keenly aware of the connection between the state of their environment and their own well-being and have suffered from what they perceive as deteriorating climatic and vegetation conditions. However, they were able to compensate for these difficulties by diversification of their livelihood strategies and, in some cases, have come to greater wealth. This resilience is not to deny the hardships and poverty that also persist in the communities.

Differences in the general trends in the variables between the greening and nongreening communities were mostly nonsignificant or weakly significant, suggesting only rainfall and livestock pressure from camels as potential driving forces behind the bioproductivity trends. The livelihood and well-being variables 
evolved more positively in the nongreening communities, indicating their decoupling from environmental conditions.

In the near-absence of spatially explicit hard data from the ground, we found that the 39 focus groups, which encompassed different regions of origin, ethnicities, and primary livelihoods, made a valuable contribution to the understanding of the complexities of the greening question by portraying a mostly coherent picture of changes. This picture exceeds prior case studies in spatial scale; however, its validity remains limited to semi-arid Senegal. In other Sahelian countries, with different economic and political situations, the same investigation might have uncovered different developments and relationships.

Responses to this article can be read online at: http://www.ecologyandsociety.org/issues/responses. $\mathrm{php} / 6710$

\section{Acknowledgments:}

This work was funded by the National Sciences Foundation Geography and Spatial Sciences Program (Grant No. 0753486). We thank Mamadou Baro (University of Arizona) and Amadou Hadj (independent consultant, Dakar, Senegal) for their help with the field work. We also acknowledge two anonymous reviewers for their valuable suggestions which helped improve this manuscript.

\section{LITERATURE CITED}

Adriansen, H. K. 2006. Continuity and change in pastoral livelihoods of Senegalese Fulani. Agriculture and Human Values 23(2):215-229. http://dx.doi.org/10.1007/s10460-005-6108-3

Adriansen, H. K. 2008. Understanding pastoral mobility: the case of Senegalese Fulani. Geographical Journal 174(3):207-222. http://dx.doi.org/10.1111/j.1475-4959.2008.00278.x

Ali, A., and T. Lebel. 2009. The Sahelian standardized rainfall index revisited. International Journal of Climatology 29 (12):1705-1714. http://dx.doi.org/10.1002/joc.1832

Anyamba, A., and C. J. Tucker. 2005. Analysis of Sahelian vegetation dynamics using NOAA-AVHRR NDVI data from 1981-2003. Journal of Arid Environments 63(3):596-614. http:// dx.doi.org/10.1016/j.jaridenv.2005.03.007

Bai, Z. G., D. L. Dent, L. Olsson, and M. E. Schaepman. 2008. Global assessment of land degradation and improvement 1. Identification by remote sensing. GLADA Report 5. ISRIC World Soil Information, Wageningen, The Netherlands. [online] URL: ftp://ftp.unccd.int/disk1/Library/Full\%20Text $\% 202011-2012 \%$ 20Full $\% 20$ Text $\% 20$ Publications/GLADAreport $\% 202008$ 01_glada $\%$ 20international rev nov $\% 202008$.pdf.

Batterbury, S. 2001. Landscapes of diversity: a local political ecology of livelihood diversification in south-western Niger. Ecumene 8(4):437-464.

Batterbury, S., and A. Warren. 1999. Land use and land degradation in southwestern Niger: change and continuity. Final report to the Global Environmental Change Initiative, ESRC. Economic and Social Research Council, Swindon, UK. [online]
URL: https://www.jircas.affrc.go.jp/project/africa dojo/Metadata/ grad_research/19.pdf.

Batterbury, S., and A. Warren. 2001. The African Sahel 25 years after the great drought: assessing progress and moving towards new agendas and approaches. Global Environmental Change 11 (1):1-8. http://dx.doi.org/10.1016/S0959-3780(00)00040-6

Blaikie, P. 1985. The political economy of soil erosion in developing countries. Longman, London, UK.

Brooks, N. 2004. Drought in the African Sahel: long term perspectives and future prospects. Tyndall Centre Working Paper 61. Tyndall Centre, University of East Anglia, Norwich, UK. [online] URL: http://www.tyndall.ac.uk/content/drought-africansahel-long-term-perspectives-and-future-prospects.

Brown, M. E., J. E. Pinzon, K. Didan, J. T. Morisette, and C. J. Tucker. 2006. Evaluation of the consistency of long-term NDVI time series derived from AVHRR, SPOT-vegetation, SeaWiFS, MODIS, and Landsat ETM+ sensors. IEEE Transactions on Geoscience and Remote Sensing 44(7):1787-1793. http://dx.doi. org/10.1109/TGRS.2005.860205

Campbell, J. R. 2001. Participatory rural appraisal as qualitative research: distinguishing methodological issues from participatory claims. Human Organization 60(4):380-389.

Chambers, R. 1981. Rapid rural appraisal: rationale and repertoire. Public Administration and Development 1(2):95-106. http://dx.doi.org/10.1002/pad.4230010202

Chambers, R. 1994. The origins and practice of participatory rural appraisal. World Development 22(7):953-969. http://dx.doi. org/10.1016/0305-750X(94)90141-4

Dahlberg, A. C., and P. M. Blaikie. 1999. Changes in landscape or in interpretation? Reflections based on the environmental and socio-economic history of a village in NE Botswana. Environment and History 5(2):127-174. http://dx.doi.org/10.3197/096734099779568335

Dai, A., P. J. Lamb, K. E. Trenberth, M. Hulme, P. D. Jones, and P. Xie. 2004. The recent Sahel drought is real. International Journal of Climatology 24(11):1323-1331. http://dx.doi.org/10.1002/ joc. 1083

DeFries, R. 2008. Terrestrial vegetation in the coupled humanearth system: contributions of remote sensing. Annual Review of Environment and Resources 33:369-390. http://dx.doi.org/10.1146/ annurev.environ.33.020107.113339

Eklundh, L., and L. Olsson. 2003. Vegetation index trends for the African Sahel 1982-1999. Geophysical Research Letters 30(8): 1430. http://dx.doi.org/10.1029/2002GL016772

Fensholt, R., K. Rasmussen, P. Kaspersen, S. Huber, S. Horion, and E. Swinnen. 2013. Assessing land degradation/recovery in the African Sahel from long-term Earth observation based primary productivity and precipitation relationships. Remote Sensing 5 (2):664-686. http://dx.doi.org/10.3390/rs5020664

Food and Agriculture Organization. 2013. FAOSTAT database. FAO, Rome, Italy. [online] URL: http://faostat3.fao.org/faostatgateway/go/to/home/E.

Fox, J., R. R. Rindfuss, S. J. Walsh, and V. Mishra, editors. 2003. People and the environment: approaches for linking household and 
community surveys to remote sensing and GIS. Kluwer, Dordrecht, The Netherlands.

Frankenberger, T. R., and M. K. McCaston. 1998. The household livelihood security concept. Food Nutrition and Agriculture 22:30-35. [online] URL: http://www.fao.org/docrep/x0051t/ x0051t05.htm.

Gonzalez, P. 2001. Desertification and a shift of forest species in the West African Sahel. Climate Research 17(2):217-228. http:// dx.doi.org/10.3354/cr017217

Gunderson, L. H., and C. S. Holling. 2002. Panarchy: understanding transformations in human and natural systems. Island Press, Washington, D.C., USA.

Hanan, N. P., Y. Prevost, A. Diouf, and O. Diallo. 1991. Assessment of desertification around deep wells in the Sahel using satellite imagery. Journal of Applied Ecology 28(1):173-186. http:// dx.doi.org/10.2307/2404123

Hanan, N. P., W. B. Sea, G. Dangelmayr, and N. Govender. 2008. Do fires in savannas consume woody biomass? A comment on approaches to modeling savanna dynamics. American Naturalist 171(6):851-856. http://dx.doi.org/10.1086/587527

Helldén, U., and C. Tottrup. 2008. Regional desertification: a global synthesis. Global and Planetary Change 64(3-4):169-176. http://dx.doi.org/10.1016/j.gloplacha.2008.10.006

Herrmann, S. M., A. Anyamba, and C. J. Tucker. 2005. Recent trends in vegetation dynamics in the African Sahel and their relationship to climate. Global Environmental Change 15 (4):394-404. http://dx.doi.org/10.1016/j.gloenvcha.2005.08.004

Herrmann, S. M., and C. F. Hutchinson. 2005. The changing contexts of the desertification debate. Journal of Arid Environments 63(3):538-555. http://dx.doi.org/10.1016/j. jaridenv.2005.03.003

Herrmann, S. M., and G. G. Tappan. 2013. Vegetation impoverishment despite greening: a case study from central Senegal. Journal of Arid Environments 90:55-66. http://dx.doi. org/10.1016/j.jaridenv.2012.10.020

Heumann, B. W., J. W. Seaquist, L. Eklundh, and P. Jönsson. 2007. AVHRR derived phenological change in the Sahel and Soudan, Africa, 1982-2005. Remote Sensing of Environment 108 (4):385-392. http://dx.doi.org/10.1016/j.rse.2006.11.024

Hickler, T., L. Eklundh, J. W. Seaquist, B. Smith, J. Ardö, L. Olsson, M. T. Sykes, and M. Sjöström. 2005. Precipitation controls Sahel greening trend. Geophysical Research Letters 32 (21): L21415. http://dx.doi.org/10.1029/2005GL024370

Hulme, M. 2001. Climatic perspectives on Sahelian desiccation: 1973-1998. Global Environmental Change 11(1):19-29. http://dx. doi.org/10.1016/S0959-3780(00)00042-X

James, M. E., and S. N. V. Kalluri. 1994. The Pathfinder AVHRR land data set: an improved coarse resolution data set for terrestrial monitoring. International Journal of Remote Sensing 15 (17):3347-3363. http://dx.doi.org/10.1080/01431169408954335

Justice, C. O., B. L. Markham, J. R. G. Townshend, and R. L. Kennard. 1989. Spatial degradation of satellite data. International Journal of Remote Sensing 10(9):1539-1561. http://dx.doi. org/10.1080/01431168908903989
Lambin, E. F., H. Geist, J. F. Reynolds, and D. M. Stafford-Smith. 2009. Coupled human-environment system approaches to desertification: linking people to pixels. Pages 3-14 in A. Röder and J. Hill, editors. Recent advances in remote sensing and geoinformation processing for land degradation assessment. Taylor \& Francis, London, UK.

Leach, H. B., C. van der Stege, and C. R. Vogl. 2011. Baobab (Adansonia digitata L.) and tamarind (Tamarindus indica L.) management strategies in the midst of conflict and change: a Dogon case study from Mali. Human Ecology 39(5):597-612. http://dx.doi.org/10.1007/s10745-011-9415-X

Leclerc, G., and O. Sy. 2011. Des indicateurs spatialisés des transhumances pastorales au Ferlo. Cybergeo 532:1-21. [online] URL: http://cybergeo.revues.org/23661.

Lind, M., K. Rasmussen, H. Adriansen, and A. Ka. 2003. Estimating vegetative productivity gradients around watering points in the rangeland of northern Senegal based on NOAA AVHRR data. Geografisk Tidsskrift 103:1-15.

Liu, J., T. Dietz, S. R. Carpenter, M. Alberti, C. Folke, E. Moran, A. N. Pell, P. Deadman, T. Kratz, J. Lubchenco, E. Ostrom, Z. Ouyang, W. Provencher, C. L. Redman, S. H. Scheider, and W. W. Taylor. 2007a. Complexity of coupled human and natural systems. Science 317:1513-1516. http://dx.doi.org/10.1126/ science. 1144004

Liu, J., T. Dietz, S. R. Carpenter, C. Folke, M. Alberti, C. L. Redman, S. H. Schneider, E. Ostrom, A. N. Pell, J. Lubchenco, W. W. Taylor, Z. Ouyang, P. Deadman, T. Kratz, and W. Provencher. 2007b. Coupled human and natural systems. Ambio 36(8):639-649. http://dx.doi.org/10.1579/0044-7447(2007)36[639: CHANS]2.0.CO;2

Liverman, D., E. F. Moran, R. R. Rindfuss, and P. C. Stern, editors. 1998. People and pixels: linking remote sensing and social science. National Academy Press, Washington, D.C., USA.

Lykke, A. M. 1998. Assessment of species composition change in savanna vegetation by means of woody plants' size class distributions and local information. Biodiversity and Conservation 7(10):1261-1275. http://dx.doi.org/10.1023/A:1008877819286

Marsh, G. P. 1864. Man and nature; or physical geography as modified by human action. Scribner, New York, New York, USA.

Mbow, C., O. Mertz, A. Diouf, K. Rasmussen, and A. Reenberg. 2008. The history of environmental change and adaptation in eastern Saloum-Senegal - driving forces and perceptions. Global and Planetary Change 64(3-4):210-221. http://dx.doi.org/10.1016/ j.gloplacha.2008.09.008

Mbow, C., T. T. Nielsen, and K. Rasmussen. 2000. Savanna fires in east-central Senegal: distribution patterns, resource management and perceptions. Human Ecology 28(4):561-583. http://dx.doi.org/10.1023/A:1026487730947

Mortimore, M., and W. M. Adams. 1999. Working the Sahel: environment and society in northern Nigeria, volume 2. Routledge, London, UK.

Mortimore, M. J., and W. M. Adams. 2001. Farmer adaptation, change and 'crisis' in the Sahel. Global Environmental Change 11 (1):49-57. http://dx.doi.org/10.1016/S0959-3780(00)00044-3 
Miehe, S., J. Kluge, H. von Wehrden, and V. Retzer. 2010. Longterm degradation of Sahelian rangeland detected by 27 years of field study in Senegal. Journal of Applied Ecology 47(3):692-700. http://dx.doi.org/10.1111/j.1365-2664.2010.01815.x

Niamir-Fuller, M. 1999. Managing mobility in African rangelands: the legitimization of transhumance. Intermediate Technology Publications, London, UK.

Nicholson, S. 2005. On the question of the "recovery" of the rains in the West African Sahel. Journal of Arid Environments 63 (3):615-641. http://dx.doi.org/10.1016/j.jaridenv.2005.03.004

Nicholson, S. E. 2013. The West African Sahel: a review of recent studies on the rainfall regime and its interannual variability. ISRN Meteorology 2013: 453521. http://dx.doi.org/10.1155/2013/453521

Nielsen, J. Ø., and A. Reenberg. 2010. Temporality and the problem with singling out climate as a current driver of change in a small West African village. Journal of Arid Environments 74 (4):464-474. http://dx.doi.org/10.1016/i.jaridenv.2009.09.019

Oba, G. 2012. Harnessing pastoralists' indigenous knowledge for rangeland management: three African case studies. Pastoralism: Research, Policy and Practice 2: 1. http://dx.doi.org/10.1186/2041-7136-2-1

Olsson, L., L. Eklundh, and J. Ardö. 2005. A recent greening of the Sahel-trends, patterns and potential causes. Journal of Arid Environments 63(3):556-566. http://dx.doi.org/10.1016/j. jaridenv.2005.03.008

Pain, R. 2004. Social geography: participatory research. Progress in Human Geography 28(5):652-663. http://dx.doi. org/10.1191/0309132504ph511pr

Pelissier, P., editor. 1983. Atlas du Sénégal. Editions Jeune Afrique, Paris, France.

Pires, M. 2012. A historical political ecology of land use in the southeastern Peanut Basin of Senegal. African Geographical Review 31(2):95-110. http://dx.doi.org/10.1080/19376812.2012.715992

Prince, S. D., E. Brown de Colstoun, and L. L. Kravitz. 1998. Evidence from rain-use efficiencies does not indicate extensive Sahelian desertification. Global Change Biology 4(4):359-374. http://dx.doi.org/10.1046/j.1365-2486.1998.00158.x

Reenberg, A., I. Maman, and P. Oksen. 2013. Twenty years of land use and livelihood changes in SE-Niger: obsolete and shortsighted adaptation to climatic and demographic pressures? Journal of Arid Environments 94:47-58. http://dx.doi.org/10.1016/ j.jaridenv.2013.03.002

Reij, C., G. Tappan, and A. Belemvire. 2005. Changing land management practices and vegetation on the Central Plateau of Burkina Faso (1968-2002). Journal of Arid Environments 63:642-659. http://dx.doi.org/10.1016/i.jaridenv.2005.03.010

Reij, C., G. Tappan, and M. Smale. 2009. Agroenvironmental transformation in the Sahel: another kind of "Green Revolution". IFPRI Discussion Paper 00914. International Food Policy Research Institute, Washington, D.C., USA. [online] URL: http:// www.ifpri.org/sites/default/files/publications/ifpridp00914.pdf.

Reynolds, J. F., and D. M. Stafford Smith. 2002. Do humans cause deserts? Pages 1-21 in J. F. Reynolds and D. M. Stafford Smith, editors. Global desertification: Do humans cause deserts? Dahlem University Press, Berlin, Germany.

Reynolds, J. F., D. M. Stafford Smith, E. F. Lambin, B. L. Turner II, M. Mortimore, S. P. J. Batterbury, T. E. Downing, H. Dowlatabadi, R. J. Fernández, J. E. Herrick, E. Huber-Sannwald, H. Jiang, R. Leemans, T. Lynam, F. T. Maestre, M. Ayarza, and B. Walker. 2007. Global desertification: building a science for dryland development. Science 316:847-851. http://dx.doi. org/10.1126/science.1131634

Salack S., B. Muller, and A. T. Gaye. 2011. Rain-based factors of high agricultural impacts over Senegal. Part I: integration of local to sub-regional trends and variability. Theoretical and Applied Climatology 106(1-2):1-22. http://dx.doi.org/10.1007/s00704-011-0414$\underline{\mathrm{Z}}$

Schoonmaker Freudenberger, K., and M. Schoonmaker Freudenberger. 1993. Fields, fallow, and flexibility: natural resource management in Ndam Mor Fademba, Senegal: results of a rapid rural appraisal carried out 25-30 October 1991. Drylands Paper 5. International Institute for Environment and Development, London, UK.

Seaquist, J. W., T. Hickler, L. Eklundh, J. Ardö, and B. W. Heumann. 2009. Disentangling the effects of climate and people on Sahel vegetation dynamics. Biogeosciences 6(3):469-477. http://dx.doi.org/10.5194/bg-6-469-2009

Seaquist, J. W., L. Olsson, J. Ardö, and L. Eklundh. 2006. Broadscale increase in NPP quantified for the African Sahel, 1982-1999. International Journal of Remote Sensing 27(22):5115-5122. http:// dx.doi.org/10.1080/01431160600868458

Sendzimir, J., C. P. Reij, and P. Magnuszewski. 2011. Rebuilding resilience in the Sahel: regreening in the Maradi and Zinder regions of Niger. Ecology and Society 16(3): 1. http://dx.doi. org/10.5751/ES-04198-160301

Sinclair, A. R. E., and J. M. Fryxell. 1985. The Sahel of Africa: ecology of a disaster. Canadian Journal of Zoology 63(5):987-994. http://dx.doi.org/10.1139/z85-147

Sissoko, K., H. van Keulen, J. Verhagen, V. Tekken, and A. Battaglini. 2011. Agriculture, livelihoods and climate change in the West African Sahel. Regional Environmental Change 11(1S): S119-S125. http://dx.doi.org/10.1007/s10113-010-0164-y

Sop, T. K., and J. Oldeland. 2013. Local perceptions of woody vegetation dynamics in the context of a 'greening Sahel': a case study from Burkina Faso. Land Degradation and Development 24 (6)511-527. http://dx.doi.org/10.1002/ldr.1144

Stafford Smith, D. M., and J. F. Reynolds. 2002 Desertification: a new paradigm for an old problem. Pages 403-424 in J. F. Reynolds and D. M. Stafford Smith, editors. Global desertification: Do humans cause deserts? Dahlem University Press, Berlin, Germany.

Stewart, D. W., P. N. Shamdasani, and D. W. Rook. 2007. Focus groups: theory and practice. Second edition. Sage, Thousand Oaks, California, USA. http://dx.doi.org/10.4135/9781412991841 
Sy, O. 2003. Dynamique des ressources en eau et évolution de la mobilité pastorale en zone sylvo-pastorale. Dissertation. Université Cheikh Anta Diop, Dakar, Senegal.

Sy, O. 2010. Aménagements hydrauliques et vulnérabilité de l'élevage transhumant au Ferlo (Sénégal). Sustentabilidade em Debate 1(2):47-60.

Tappan, G. G., M. Sall, E. C. Wood, and M. Cushing. 2004. Ecoregions and land cover trends in Senegal. Journal of Arid Environments 59(3):427-462. http://dx.doi.org/10.1016/j. jaridenv.2004.03.018

Thomas, W. L. 1956. Man's role in changing the face of the Earth. University of Chicago Press, Chicago, Illinois, USA.

Tucker, C. J. 1979. Red and photographic infrared linear combinations for monitoring vegetation. Remote Sensing of Environment 8(2):127-150. http://dx.doi.org/10.1016/0034-4257 (79)90013-0

Tucker, C. J., H. E. Dregne, and W. W. Newcomb. 1991. Expansion and contraction of the Sahara Desert from 1980 to 1990. Science 253:299-301. http://dx.doi.org/10.1126/science.253.5017.299

Tucker, C. J., J. E. Pinzon, M. E. Brown, D. A. Slayback, E. W. Pak, R. Mahoney, E. F. Vermote, and N. El Saleous. 2005. An extended AVHRR 8-km NDVI dataset compatible with MODIS and SPOT vegetation NDVI data. International Journal of Remote Sensing 26(20):4485-4498. http://dx.doi.org/10.1080/01431160500168686

Turner, B. L. II, and P. Robbins. 2008. Land-change science and political ecology: similarities, differences, and implications for sustainability science. Annual Review of Environment and Resources 33:295-316. http://dx.doi.org/10.1146/annurev. environ.33.022207.104943

Warren, A. 2002. Land degradation is contextual. Land Degradation and Development 13(6):449-459. http://dx.doi. org/10.1002/1dr.532

Warren, A., and C. Agnew. 1988. An assessment of desertification and land degradation in arid and semi-arid areas. International Institute for Environment and Development Paper 2. International Institute for Environment and Development, London, UK.

World Bank. 1998. Indigenous knowledge for development: a framework for development. World Bank, Washington, D.C., USA. [online] URL: http://www.worldbank.org/afr/ik/ikrept. pdf.

World Bank. 2013. World dataBank. World Bank, Washington, D.C., USA. [online] URL: http://databank.worldbank.org/data/ home.aspx. 